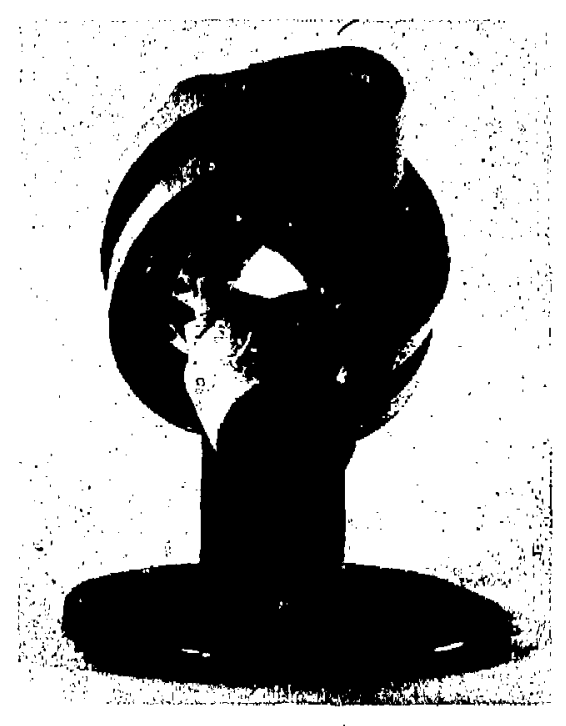

CASE FAULT ANALYSIS FOR THE MIIRROR FUSION TEST FACILITY (MFTF) MAGNET SYSTEM

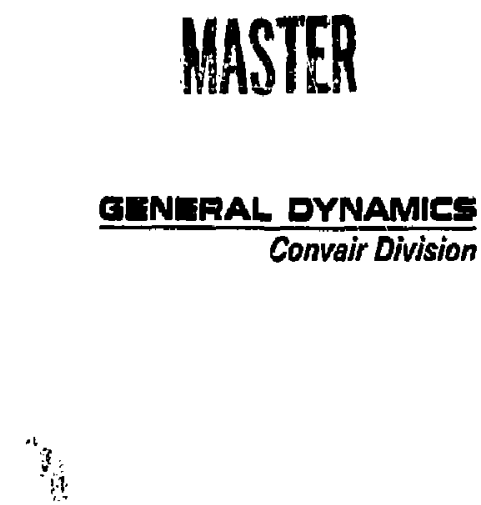




\section{CASE FAULT ANALYSIS FOR THE MIRROR FUSION TEST FACILITY (MFTF) MAGNE' SYSTEM}

March 1979

A. W. Baldi

C. 0. Poniktera

Prepared Under Contract 9815603

Prepared for

UNIVERSITY OF CALIFORNIA

LAWRENCE LIVERMORE LABORATORY

P.0. Box 5012 (L-446)

Livermore, California 94550

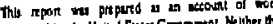

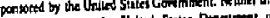

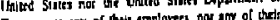

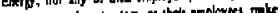

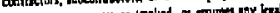

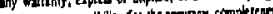

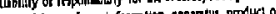

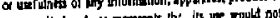

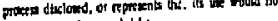
thefringe prive tely thined itho.

Prepared by GENERAL DYNAMICS CONVAIR DIVISION

P.0. Box 80847

San Diego, Califfomia 92138 
THS DOCUMENT PREPARED BY

GENERAL DYNAMICS/CONVAIR

AND APPROVED BY
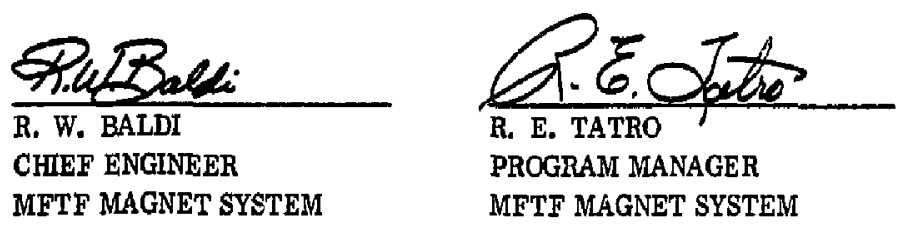


\section{TABLE OF CONTENTS}

1 INTRODUCTION 1

2 STRUCTURAL REQUTREMENTS 2

2.1 MATERIAL PROPERTIES 2

2.2 FACTORS OF SAFETY 2

3 ANALYSIS

3.1 INTRODUCTION 5

3.2 BASELINE

3.3 FAULT NO, 1: MINOR RADIUS INTERMEDLATE 3 TO 5 INCH PLATE INTERSECTION IN THE CHAMFER REGION AT THE CENTERLINE OF SYMMETRY

3.3.1 Selection Rationale 6

3.3.2 Analysis Methodology 6

3.3.3 Analysis Results 12

3.4 FAULT NO. 2; CONDUCTOR PACK JACKET CLOSE-OUT WELD IN THE MAJOR TO MINOR RADIUS TRANSITION

3.4.1 Selection Rationale 12

3.4.2 Analysis Methodology 16

3.4.3 Analysis Results 16

3.5 FAULT NO. 3: INTERCOIL MEMBER SHEAR TRANSFER WELD, BOTTOM CLOSURE PLATE TO SDE PLATE CORNER WELD

3.5.1 Selection Rationale 19

3. 5.2 A.alysis Methodology 19

3.5.3 Analysis Results 19

3.6 FAULT NO, 4: 3-INCH PLATE CLOSE-OUT WELD AT THE CENTER LINE OF SYMMETRY IN THE MINOR RADIUS AT THE BOTTOM OF THE 9 SECTION

3.6.1 Selection Rationale 23

3.6.2 Anaiysis Methodology 23

3.6.3 Analysis Results 23 
TABLE OF CONTENTS (Continued)

Section

$\underline{\text { Page }}$

3.7 FAULT NO. 5: MAJOR TO MINOR RADIUS

TRANSITION, 3 TO 5 INCH BUTT WELD JOINT

ON THE CONDUCTOR CASE TOP PLATE

3.7,1 Selection Rationale 25

3.7.2 Analysis Methodology 25

3.7.3 Analysis Results 25

4 CONCLUSIONS

5 RECOMMENDATIONS

6 REFERENCES 36

APPENDIX A: MFTF CASE FAULT ANALYSIS: BASELINE MODEL A-1

GDSAP COMPUTER ANALYSIS RESULTS

APPENDIX B: MFTF CASE FAULT ANALYSIS: FAULT NO. 1, B-1 MINOR RADIUS INTERMEDLATE 3 TO 5 INCH PLAT: INTERSECTION IN THE CHAMFER REGION AT THE CENTER LINE OF SYMMETRY, GDSAP MODEL COMLPUTER ANALYSIS RESULTS

APPENDLX C: MFTF CASE FAULT ANALYSIS: FAULT NO. 2, CONDUCTOR PACK JACKET CLOSE-OUT WELD IN: THE MAJOR TO MINOR RADIUS TRANSITION, GDSAP MODEL COMPUTER ANALYSIS RESULTS

APPENDIX D: MFTF CASE FAULT ANALYSIS: FAULT NO. 3, INTELCOIL MEMBER SHEAR TRANSFER WELD (BOTTOM CLOSURE PLATE TO SIDE PLATE CORNER WELD), GDSAP MODEL COMPUTEK ANALYSIS RESULTS

APPENDLX E: MFTF CASE FAULT AYALYSIS: FAULT NO. 4, E-1 3-INCH PLATE CLOSE-OUT WELD AT THE CENTER LINE OF SYMMETRY IN THE MINOR RADITS AT THE BOTTOM OF THE 9 SECTION, GDSAP MODEL COMPUTER ANALYSIS RESULTS

APPENDIX F: MFTF CASE FAULT ANALYSIS: FAULT NO. 5 , F-1 MAJOR TO MINOR RADIUS TRANSITION 3 TO 5 INCH EUT'T WELD JOINT ON THE CONDUCTOR CASE TOP PLATE, GDSAP MODEL COMPUTER ANALYSIS RESULTS 


\section{LIST OF FIGURES}

Figure

1.1 MFTF GDSAP Finite Element Model

3.1 Baseline Model Peak Principal Stresses ?

3.2 Baseline Model Case Crossover Plate Principal Stresses B

3.3 Baseline Model Case Side Plate Principal Stresses 9

3.4 Baseline Model Corner Longitudinal Stresses 10

3.5 Fault Condition Number $1 \quad 11$

3.6 Fault Condition No. 1 - Baseline Plating Principal Stress Comparison (Case Side Locations) 13

3.7 Fault Condition No. 1 - Baseline Plating Principal Stress Comparison (Case Crossover Locations) 14

$3.8 \quad$ Fault Condtion Number $2 \quad 15$

3.9 Fault No. 2 - Longitudinal Stresses at Top of L Section 0.5 in. Jacket Close-Cut Plate 17

3.10 Fault No. 2 - Longitudinal Stresses at Bottom of $L$ Sectlon 0.5 in. Jacket Close-Out P!ate 18

$2.11 \quad$ Fault Condition Number $3 \quad 20$

3.12 Intercoll Structure Loads for Baseline No. 6 (Magnetic Loads Oaly)

3.1i Intercoil Structure Loads for Fault No. 3 (Magnetic Loads Only)

3.14 jault Condition Number $4 \quad 34$

3.15 Fault Condition Numbar $5 \quad 26$

3.16 Fault No. 5- Baseline Model Plate Membrane Stress Comparison $\quad 27$

3.17 Fault No. 5 - Baseline Model Plate Bending Stress Comparison

3.18 Fault No. 5 - Baseline Model Selected Plate Principal Stress Comparison 


\section{LBST OF FIGURES (Continued)}

Figure

Page

3.19 Fault No. 5; Longitudinal Stresses Along Case Top Outside Comer

30

3.20 Fault No. 5: Longltudinal Stresses Along Case Top Inside Comer

31

\section{LIST OF TABLES}

Table

Page

2.1 Structural Material Mechanical Properties

3

2.2 MFTF Case Material Fracture Analysis Properties

4.1 R zults Summary

34 


\section{STIMMARY}

This report describes the stress analysis performed to determine the criticality of selected fallures in the magnet case, jacket, and intercoll member.

Since this task was a follow-on to the program that confirmed the structural integrity of the MFTF mognet case, jacket, and shield system (Ref. 1), every effort was made to utilize analysis methods and tools developed during that program. Figure 1.1 illustrated the large, 5000 degree of freedom GDSAP model developed during that program which was used extensively throughout this analysis task. This model accurately represents the case and jacket structure and simulates the conductor pack stiffness with an array of interconnected rod elements. All results contained in the report are besed on linear-elastic, small deflection theory.

The selected faults were idealized by adding additional nodes coincidental to existing nodes in the baseline finite element model and changing fault boundary plate connectivities. No attempt was made to alter the analysis mesh size adjacent to any fault as this degree of effort was beyond the intent and scope of this task.

Subsequent to the finite element computer analysis of each assumed fault condition, deflection data was extracted from the computer output data to determine the tensile stress normal to the approaching fault front. Using this stress data, a Mode I linearelastic fracture mechanics analysis was performed to quanify the criticality of each fault.

Results of this analysis indicated that two of the five faults analyzed would be catastrophic in nature. Faults of this category are:

Fault No. 1 - A weld joint failure in the minor radius 3 to 5 inch plate intersection in the chamfer region at the centerline of symmetry. (Ref. Figure 3.5)

Fault No. 5 - Failure of the 3 to 5 inch rransition butt weld joint at the major to minor radius transition on the magnet case tup plaie. (Ref. Figure 3. 15)

In addition, another one of the iaults analyzed was determined to be potentially catastrophic, 1.e., it would continue io propagate under cylic loading until catastrophic failure occurs unless arrested. This fault was fault No, 4, which simulated the fallure of the close-out weld in the 3.0-inch plate at the centerline of symmetry in the minor radlus at the bottom of the 9 section. (Ref. Figure 3.14) 


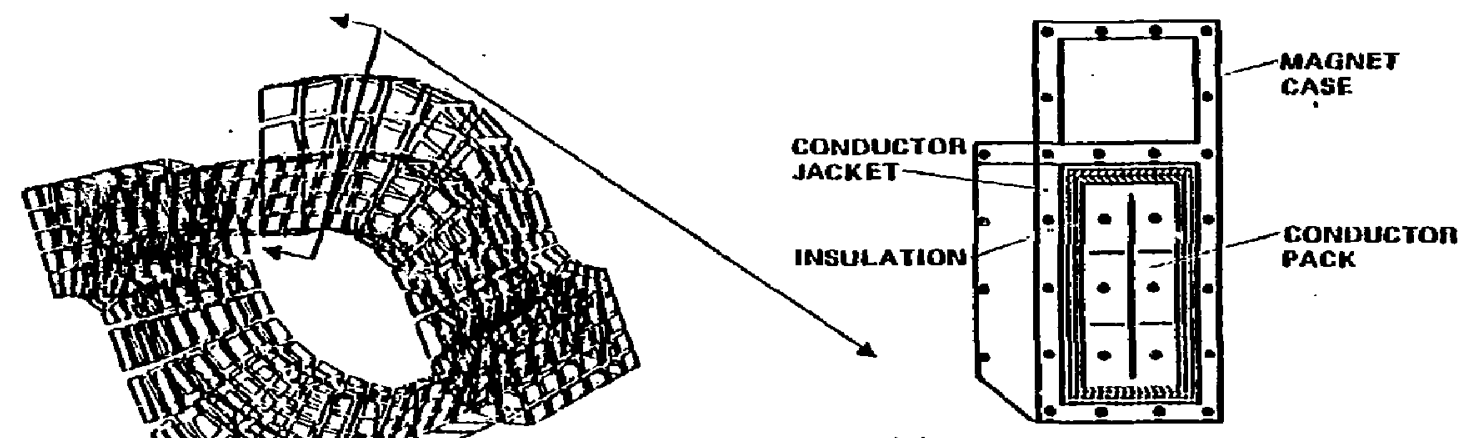

(A) TYPICAL NODE AHHANGEMENT

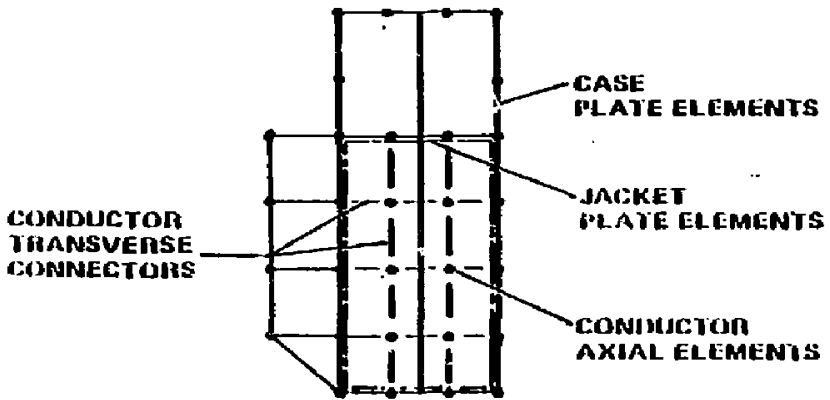

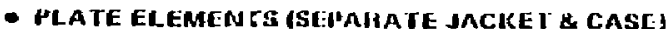

(13) TYIHI:AL MOULL :OROSS SECTEON

Figure 1. 1. MFTF GDSAP Finite Element Model 
Analysis of fault No, 2, the failure of the closemout weld in the 0.5 -inch jacket plate it the major to minor radlus transition, indicated that the jacket would fail under cyclic loading. Hivever, comparison of the resulting stresses in the case plates beiore and after jacket fature incicate that the ystem, as a whole, will not experience a significant increase 43 local. stresses.

In addition, an intercoil member fault condition was analyzed. Implications of this analysis are inconclusive as review of the firite elernent rdsults of this simulated fault condition indicate no siguificant rectistribution us stresses. This is probabiy a consequence of the model mesh size adjacent to the fault boundary. Decreasing the mesh size would have inticated local peaking effects and allowed a more acsurate appraisal as to the impact of this assumed fault condition. However, additional study of this fault condition does not appear tu be warranted.

As a result of this study the following recommendatons were made:

1. A periodic magnet inspection plan be develcped and insplemented for critical areus.

2. ill urder to more accurately represent the structural behavior in the presencs of a crack tip, future fault aralyses should utilize a non-linear finite element code (such as MARC) that has that capability.

3. If a linear code such as GDSAP is used for future fault analysis purposes, the mesh size adjacent to fault boundaries sbould be reduced to more accurateiy predict local peaking effects. 


\section{INTRODUCTION}

This report documents the stress analyses for the MFTF magnet system fatlt analysis task. The analysis is based on LLL requirements to determine the criticality of selected failures in the magnet case, jacket, and intercoil structure.

As a logical follow-on to the program that confirmed the structural integrity of the MFTF nagnet case, jacket, and shield system (Ref. 1), every effort was made to utilize analysis methods and tools developed during that program. Figure 1.1 illustrated the large, 5000 degree of freedom GDSAP model developed during that program which was used extensively throughout this analysis task. This model accurately represents the case and jacket structure and simulates the conductor pack stiffness with an array of interconnected rod elements. All results contained in the report are based on linear-elastic, small deflection theory.

The results of the finite element analysis that form the basis of the work contained hcrein are summarized in Section 3. Details of the finite element model may be found in Ref. 1, Appendix A, Vol. I.

Detailed computer output, including plate margin of safety summaries and plate margin of safety comparisons to the baseline model, are contained in Appendices A through $F$. 


\section{STRUCTURAL REQUIREMENTS}

\subsection{MATERLAL PROPERTIES}

The mechanical properties and fracture analysis materials data for the MFTF structural materials are listed in Tables 2.1 and 2.2, respectively. In the case of E316L welds, flaw growth rate data was unavailable. For analysis purposes, data was estimated from 310S with E320-16 filler sata. The yield strtigths in Table 2.1 for the E316L welds and the $304 \mathrm{LN}$ plate are less than the $120 \mathrm{ksi}$ design values defined by LLL. It is expected that $120 \mathrm{ksi}$ yleld strengths will be obtained through increase in nitrogen content in 304LN and control of delta ferrite content in the $316 \mathrm{~L}$ welds. For design purposes, the mechanical properiles of the 304Ly and 316L were used as shown in Table 2.1 except for the use of an assumed $120 \mathrm{ksi}$ yield strength.

\subsection{FACTORS OF SAFETY}

As this study concerns structural analysis of fauli conditions, conventional factor of safety requirements are not presented. However, margin of safety fault/baseline nodel compariscns are presented in the Appendices. These comparisons are based on a factor of safety of 1.5 on yield strength. 
Table 2.1. Structural Material Mechanical Properties

\begin{tabular}{|c|c|c|c|c|c|c|}
\hline Material & Usage & $\begin{array}{c}\text { Teimp } \\
{ }^{\circ} \mathrm{K} \\
\end{array}$ & $\begin{array}{r}\mathbf{F}_{\text {TU }} \\
\text { (ksi) }\end{array}$ & $\begin{array}{c}F_{\mathrm{TY}} \\
\text { (ksi) }\end{array}$ & $\begin{array}{c}E \\
10^{6} \\
(\mathrm{psi})\end{array}$ & Source \\
\hline $304 L$ & Support Struts & $\begin{array}{l}\mathrm{RT} \\
4.5\end{array}$ & $\begin{array}{l}100 \\
245\end{array}$ & $\begin{array}{l}40 \\
70\end{array}$ & $\begin{array}{l}28.5 \\
29.6\end{array}$ & LLL \\
\hline 304LN & $\begin{array}{l}\text { Magnet Case and } \\
\text { Intercoil }\end{array}$ & 4.5 & 244.6 & $111.8 *$ & 29.7 & NBS \\
\hline E316L $\quad \begin{aligned} \Delta \mathrm{Fe} & =4.5 \\
\Delta \mathrm{Fe} & =9.2\end{aligned}$ & Case Weld Metal & $\begin{array}{l}4.5 \\
4.5\end{array}$ & $\begin{array}{l}193 \\
187\end{array}$ & $\begin{array}{l}116 * \\
128 *\end{array}$ & $\begin{array}{l}31.9 \\
31.9\end{array}$ & NBS \\
\hline $316 L$ & Jacket & $\begin{array}{l}\text { RT } \\
4.5\end{array}$ & $\begin{array}{r}80 \\
200\end{array}$ & $\begin{array}{l}40 \\
80\end{array}$ & $\begin{array}{l}29.5 \\
31.9\end{array}$ & \\
\hline $\begin{array}{l}\text { EPON } 828 / \text { Versamid } 125 \\
\text { with Clopped Glass Fiber }\end{array}$ & Conductor Shimming & $20^{\circ}$ & -14700 & - & - & $\begin{array}{l}\text { GDC EMS } \\
0-0096-51\end{array}$ \\
\hline $\begin{array}{l}\text { CPR Upjohn } \\
\text { Polycast 1009-78 }\end{array}$ & Jackel to Case & RT & -13250 & - & .387 & Mfgr Data \\
\hline A286 & Support Bolts & $1 B T$ & 140 & 95 & 29.1 & AMS $5737 \mathrm{H}$ \\
\hline
\end{tabular}


Table 2.2. MrrF Case Material Fracture Analysis Proportles

\begin{tabular}{|c|c|c|c|c|c|c|}
\hline Malouial & $\begin{array}{l}\text { Temp } \\
\text { ('K) }\end{array}$ & $\begin{array}{l}\mathbf{F}_{\mathbf{T Y}} \\
(\mathrm{ksi})\end{array}$ & $\begin{array}{r}\mathrm{K} \\
(\mathrm{ksi} \\
\end{array}$ & in.) & $\begin{array}{c}\text { da/dN } \\
\text { Flaw Growth Rate } \\
\mu \text { in./Cyclo }\end{array}$ & Source \\
\hline $304 \mathrm{LN}(0.12 \% \mathrm{~N})$ & 4.5 & 111.8 & 203 & & $1.054 \times 10^{-4}(\Delta \mathrm{K})^{3.59}$ & 1 \\
\hline \multicolumn{7}{|l|}{ E316L Weld Filler } \\
\hline$\Delta F e=4.5$ & 4.5 & 116 & 110 & & Not available & 1 \\
\hline$\Delta F e=9.2$ & 4.5 & 128 & 95 & & Not available & 1 \\
\hline $\begin{array}{l}\text { E3I0-16 Weld Filler } \\
\text { (AISI 310S, SMAW) }\end{array}$ & 4.2 & 120 & 106 & 3 & $4.98 \times 10^{-8}(\Delta K)^{5.15}$ & 1 \\
\hline
\end{tabular}




\section{ANALYSTS}

\subsection{INTRODUCTION}

The objective of this fault analysis was to determine the criticality of selected failures in the magnet case, facket, and intercoil member. These fault analyses were accomplished using the GDSAP finite element model developed during the initial structural analysis of the magnet system. All analyses accomplished herein are linear elastic and based on small deflection theory.

A total of five fault conditions were analyzed during this study. Isometric sketches, selection rationale, and analysis results are presented in subsequent sections for each of the following faults:

1. Minor radius intermediate 3 to 5 inch plate intersection in the chamfer region at center line of symmetry

2. Conductor pack jacket close-out weld in the major to minor radius transition.

3. Intercoil member shear transfer weld, bottom closure plate to side plate corner weld.

4. The 3-inch close-out weld at the center line of symmetry in the minor racius at the bottom of the 9 section.

5. The 3 to 5 inch transition butt weld joint at the major to minor radius transition on the conductor case top plate.

Appendix A contains a plate margin of safety summary and the complete computer printout for the baseline (no-fault) configuration model. This baseline model is slightly different from the analysis model used in the MFTF design analysis. The triangular plate elements used in the minor radius chamfered region of the design analysis model were replaced by quadrilatemal elements in the fault analysis baseline model in an atlempt to increase the accuracy of the anaiysis. Also, some electromagnetic load discrepancies found in the design analysis model were corrected. Appendices B through $F$ contain the above material and comparisons between the plate margins of safety for the baseline model and each fault condition.

\subsection{BASELINE}

The baseline analysis contained herein is based on conductor pack connectivity scheme No. 6 arrived at during the conductor pack analysis task (Ref. 2). 
Figure 3.1 presents peak principal stresses in the case plates for the combined magnetic plus thermal (nornal operating) load combination. Figures 3.2 and 3.3 present principal stresses at selected locations for the magnetic loads case only,

Figure 3.4 is of particular importance as it displays the longitudinal stresses close to each comer of the conductor pack and vacuum guard cases. These stresses were developed by simple $\mathrm{Al} / \mathrm{l}$ calculations using the GDSAP analysis output nodal deflection data. For several analysis conditions it is these stresses that will determine the criticality of an assumed fault.

Appendix A contains a plate margin of safety summary and the complete computer printout for the baseline configuration model.

\subsection{FAULT NO. 1: MINOR RADIUS INTERMEDLATE 3 TO 5 INCH PLATE INTER-} SECTION IN THE CHAMFER REGION AT THE CENTERLINE OF SYMMETRY

\subsubsection{SELECTION RATIONALE}

Fault No. 1 is displayed graphically in Figure 3.5. The selection rationale for this fault follows:

- Weld Joint

- Complex unbalanced weld-on-weld joint

- Heat sink gradient

- Joint Geometry

- Chamfer region increases welding difficulty but has no significant effect on gross stress distribution

- Stress

- Plate membrane stresses parallel to this weld joint approach $80 \mathrm{ksi}$ (Ref, 1)

- Principal stresses in the $5^{\prime \prime}$ plate approach $80 \mathrm{ksi}$ (Ref. 1)

- Concern

- Loss of the 5 to 3 inch joint (basically a shear transfer member) may result in excessive case deflection and subsequent conductor pack crushing

\subsubsection{ANALYSIS METHODOLOGY}

Concident Brids points were installed at the intersection of the 5-inch cross-over and 3-Inch case side plate at the chanfer region. Continuous connectivity was provided for in the 3-Inch plate while connectivity in the 5-inch was interrupted throughout a $20^{\circ}$ arc (approximately 6.82 inches). 

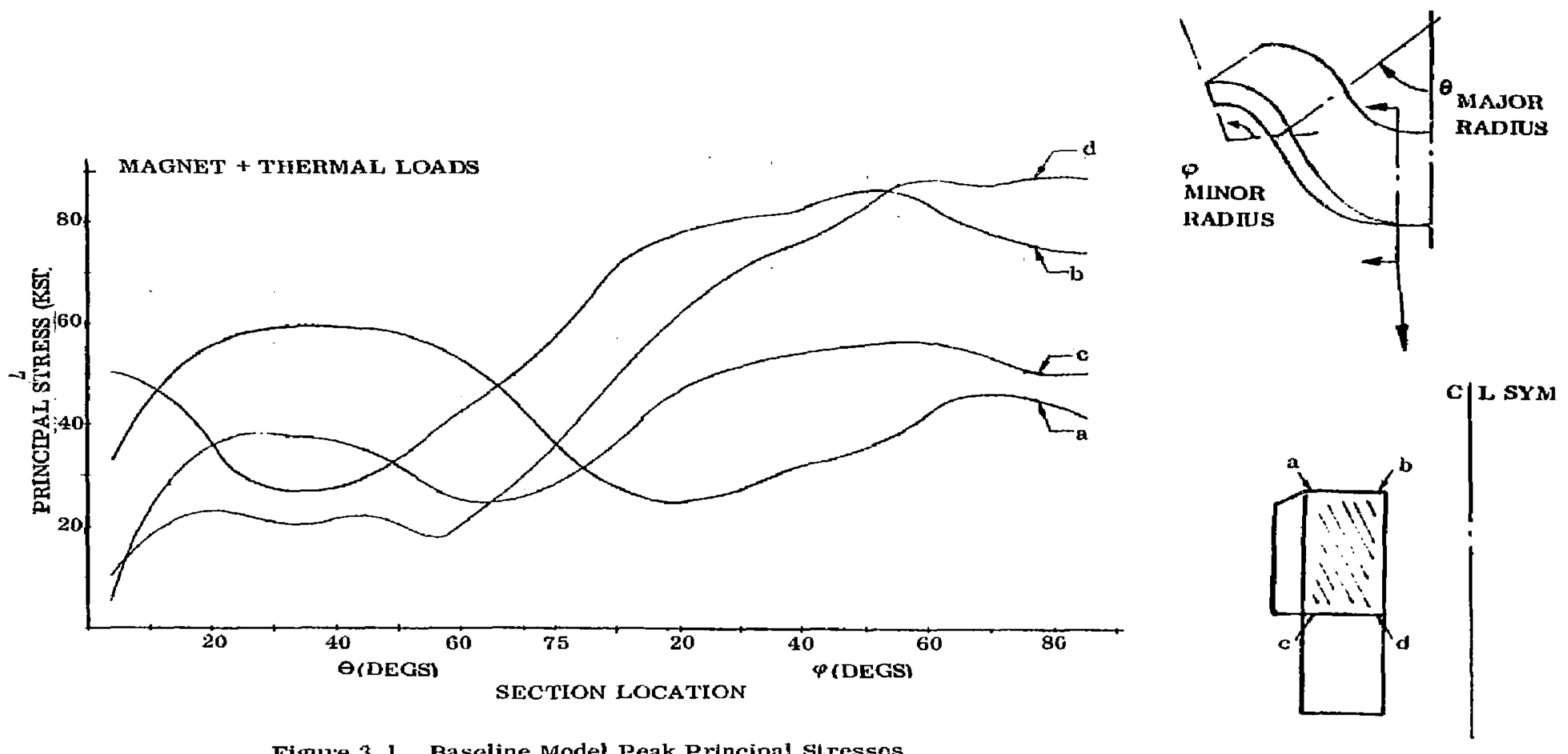

Figure 3. 1. Baseline Model Peak Principal Stresses 

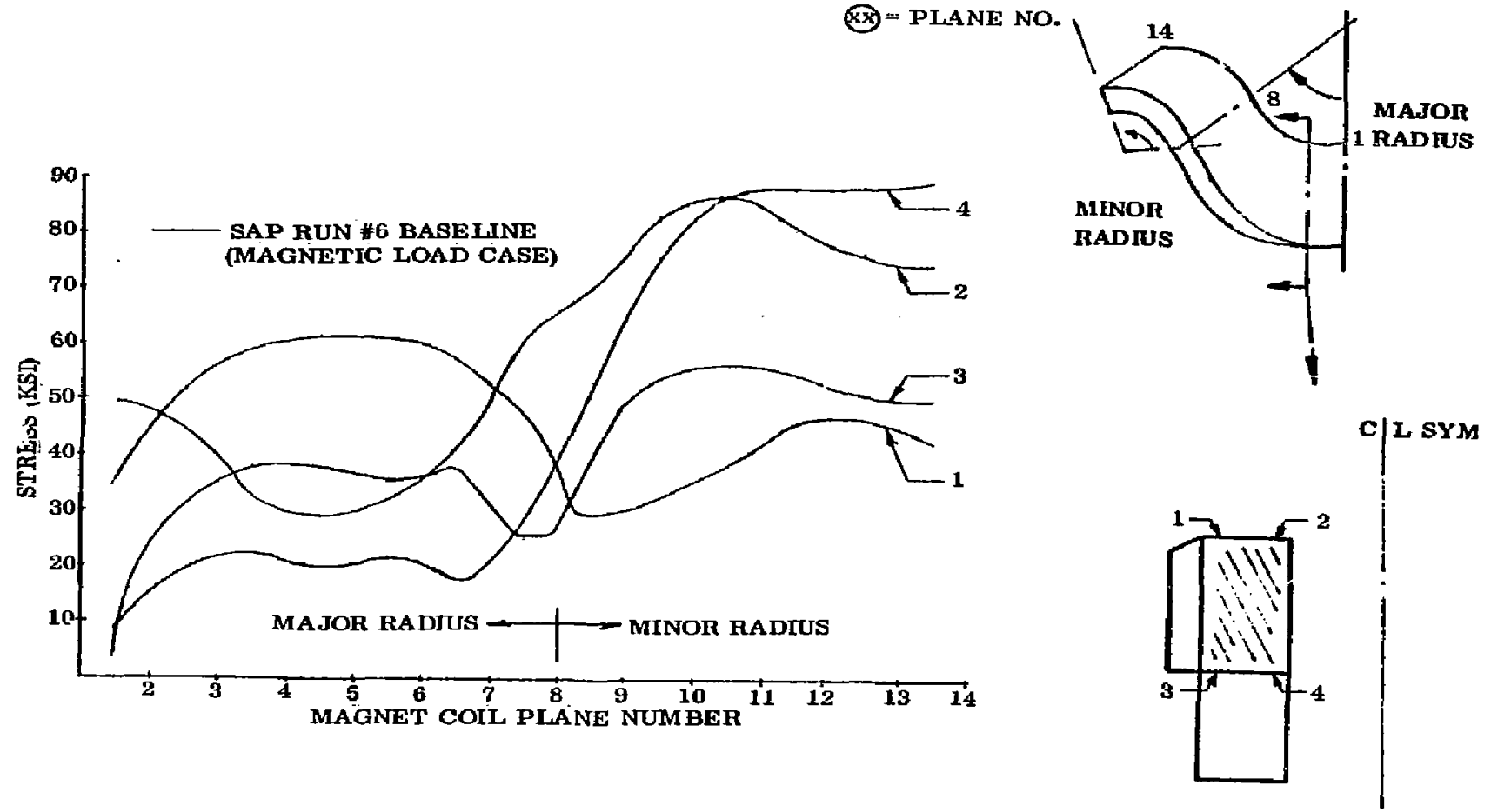

Figure 3.2. Baseline Model Case Crose ivor Plate Principal strosses 


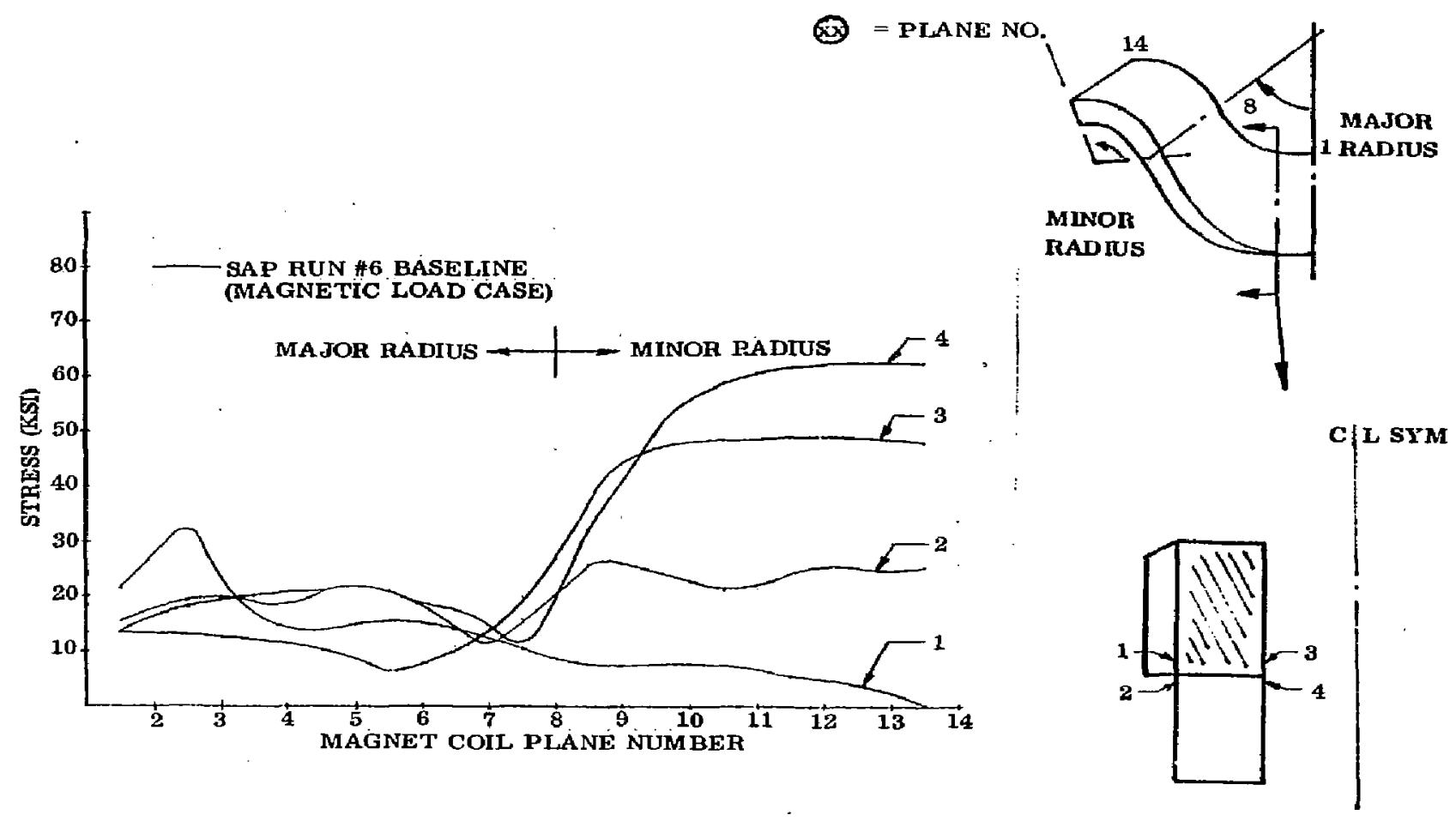

Figure 3.3. Baseline Model Cage Side Plate Principal Stregses 

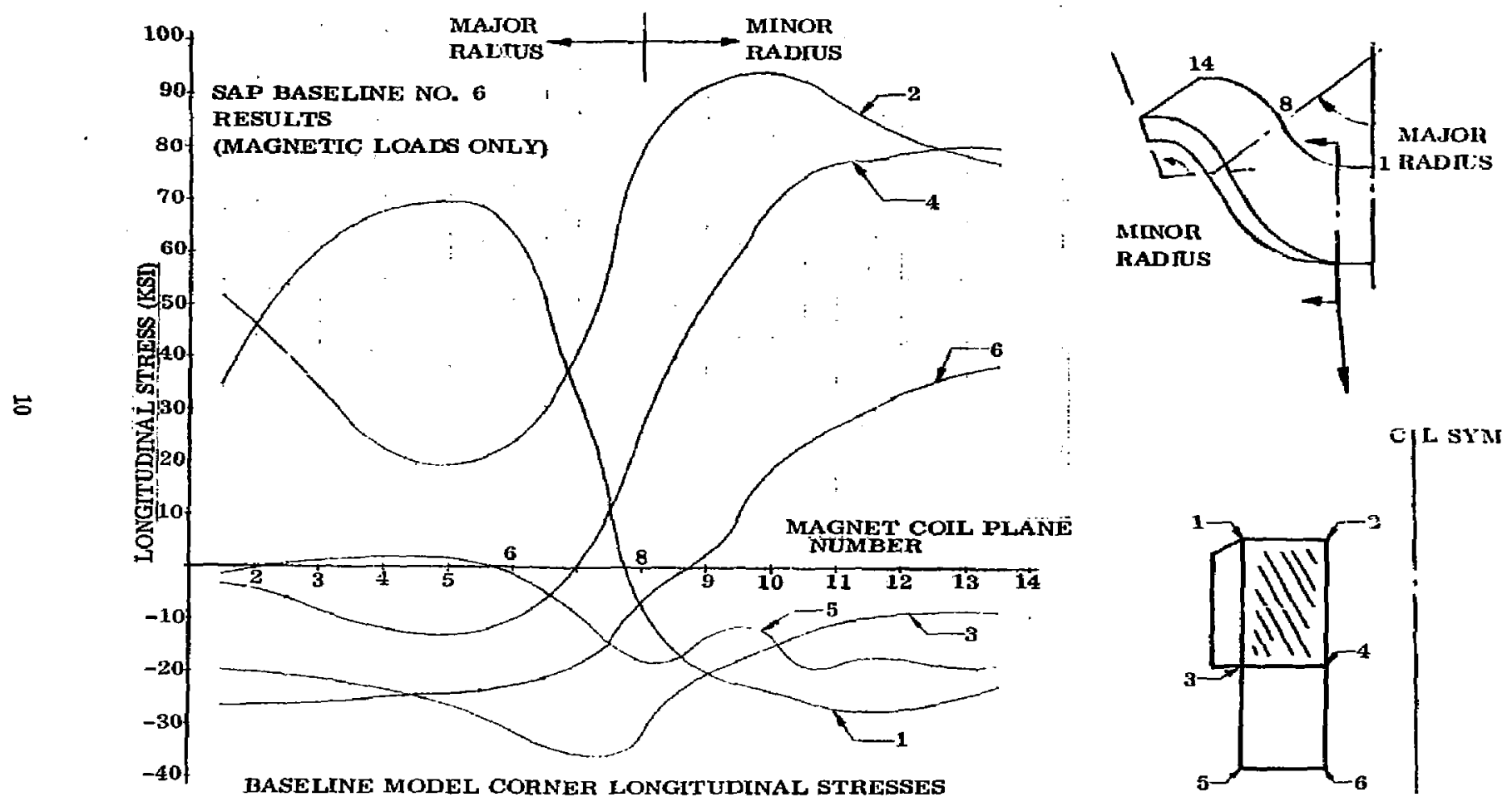

Figure 3. 4. Baseline Model Corner Longitudinal Stresses 


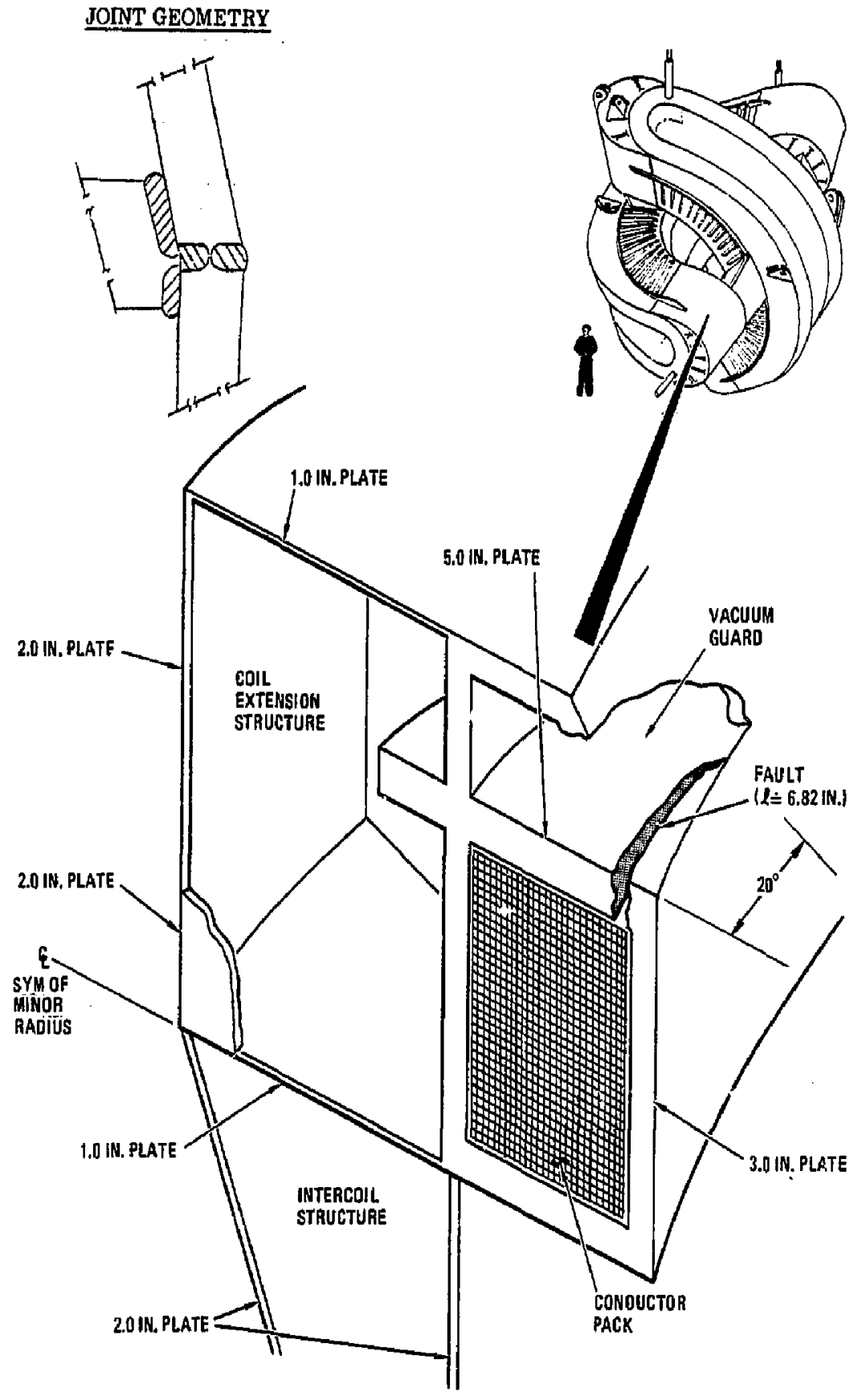

Figure 3.5. Fault Condtion Number 1 


\subsubsection{ANALYSIS RESULTS}

Figures 3.6 and 3.7 compare principal stresses for this fault condition with baceline principal stresses for selected locattons. To determino the tersile stress normal to the approaching fault front, deflection data was extracted from the SAP solution computer output. This normal stress is required to determine the criticality of a flaw using linear elastic fracture mechanics analysis techniques (Mode I analysis).

Analysis of the 5-inch plate deflection data Indicates that the stress field normal to the approaching fault front is approximately 25,880 psi, neglecting bending. Assuming an infinite plate with a flinite crack,

$$
\begin{aligned}
K_{I} & =\sigma \sqrt{\pi a} \quad \text { (Ref. 3) } \\
& =25880 \sqrt{6.82 \pi} \\
& =120 \mathrm{ksi} \sqrt{\mathrm{in} .}
\end{aligned}
$$

Previous fracture mechanics analyses (Ref. 1) have reported a $\mathrm{K}_{\mathrm{IC}}$ value for E316

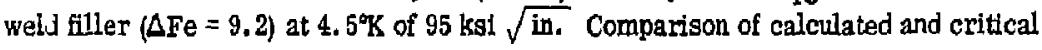
stress intensity values indicates that thils fault would continue to propagate under stitic loading until a lower stress field is encountered or $c$ orack arrest mechanism is encountered.

\subsection{FAULT NO, 2: CONDUCTOR PACK JACKET CLOSE-OUT WELD IN THE MA.TOR TO MINOR RADIUS TRANSITION}

\subsubsection{SELECTION RATIONALE}

Fault No. 2 is displayed graphically in Figure 3.8. The selection rationale for this fault follows:

- Weld Joint

- Close-out weld increases weld inspection difficulty

- Joint Geometry

- Joint orlented normal to significant plate membrane stresses

\section{- Stresses}

- Princlpal stresses in the area of the joint approach $50 \mathrm{ksi}$ (Ref. 1) 

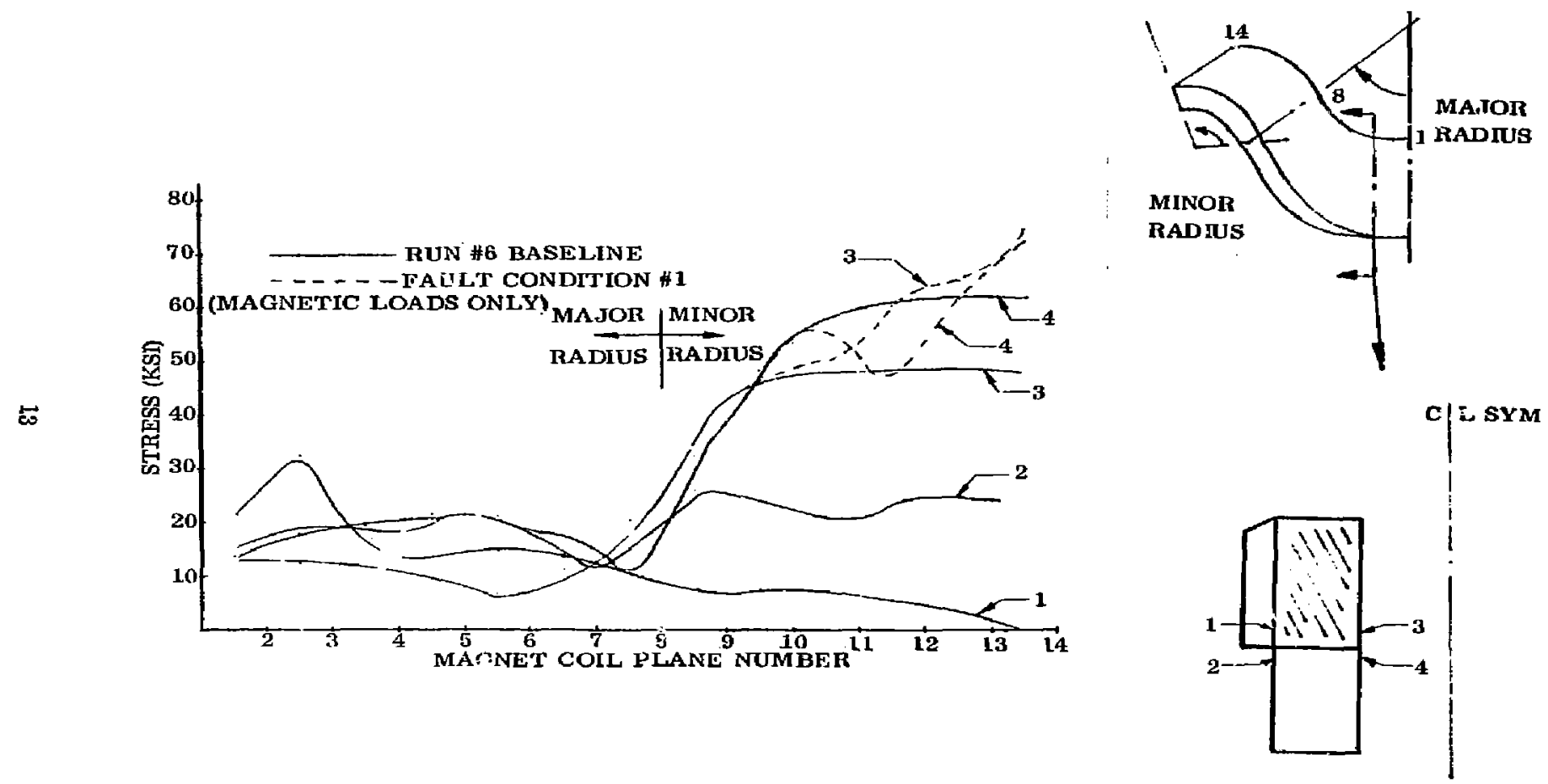

Figure 3. 6. Fault Condition No. 1-Baseline Platirg Prineipal Stress Compartson (Case Side Locations) 

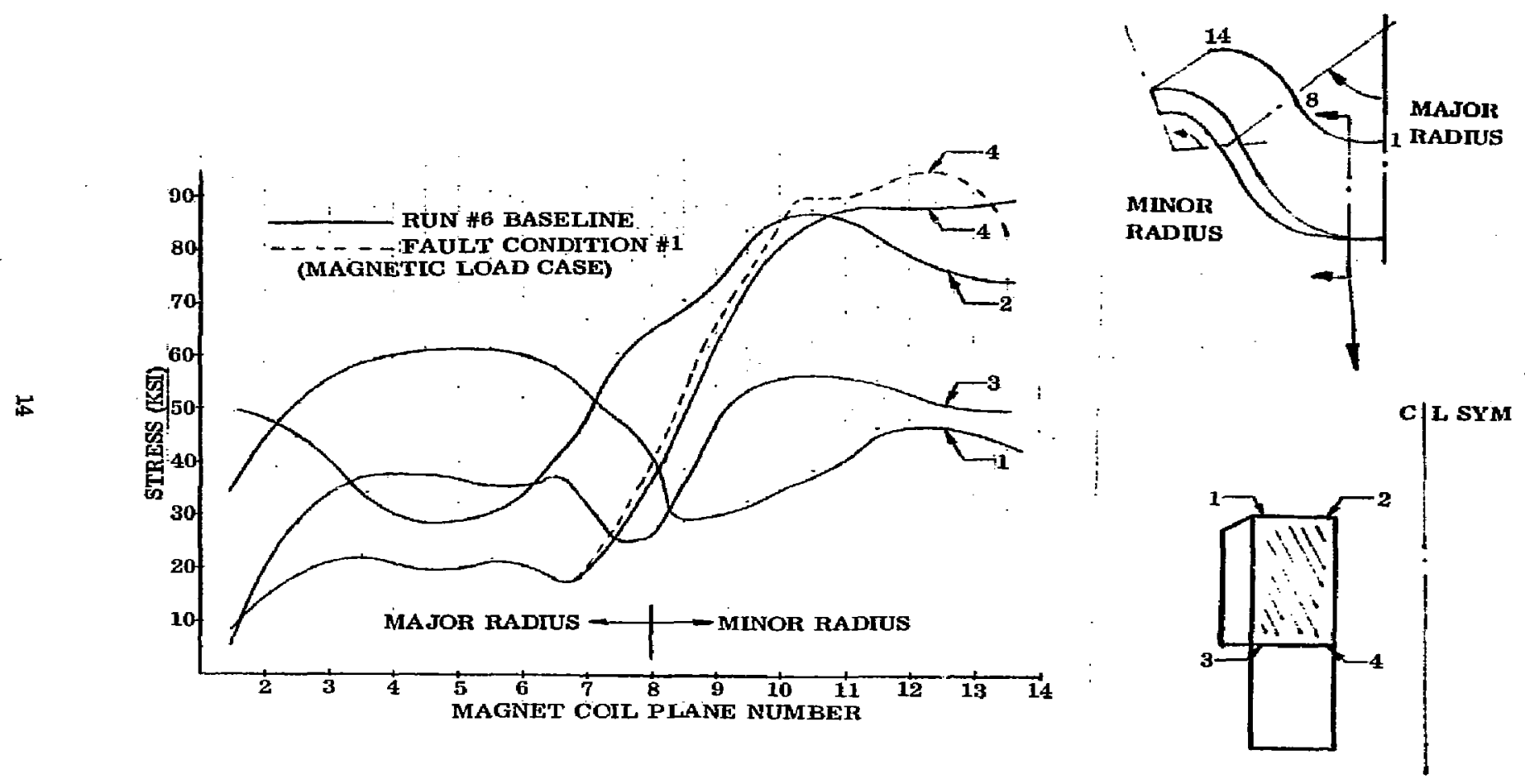

Figure 3. 7. Fault Condition No, 1 - Baseline Plating Principal s:ress Comparison (Case Crossover Locations) 


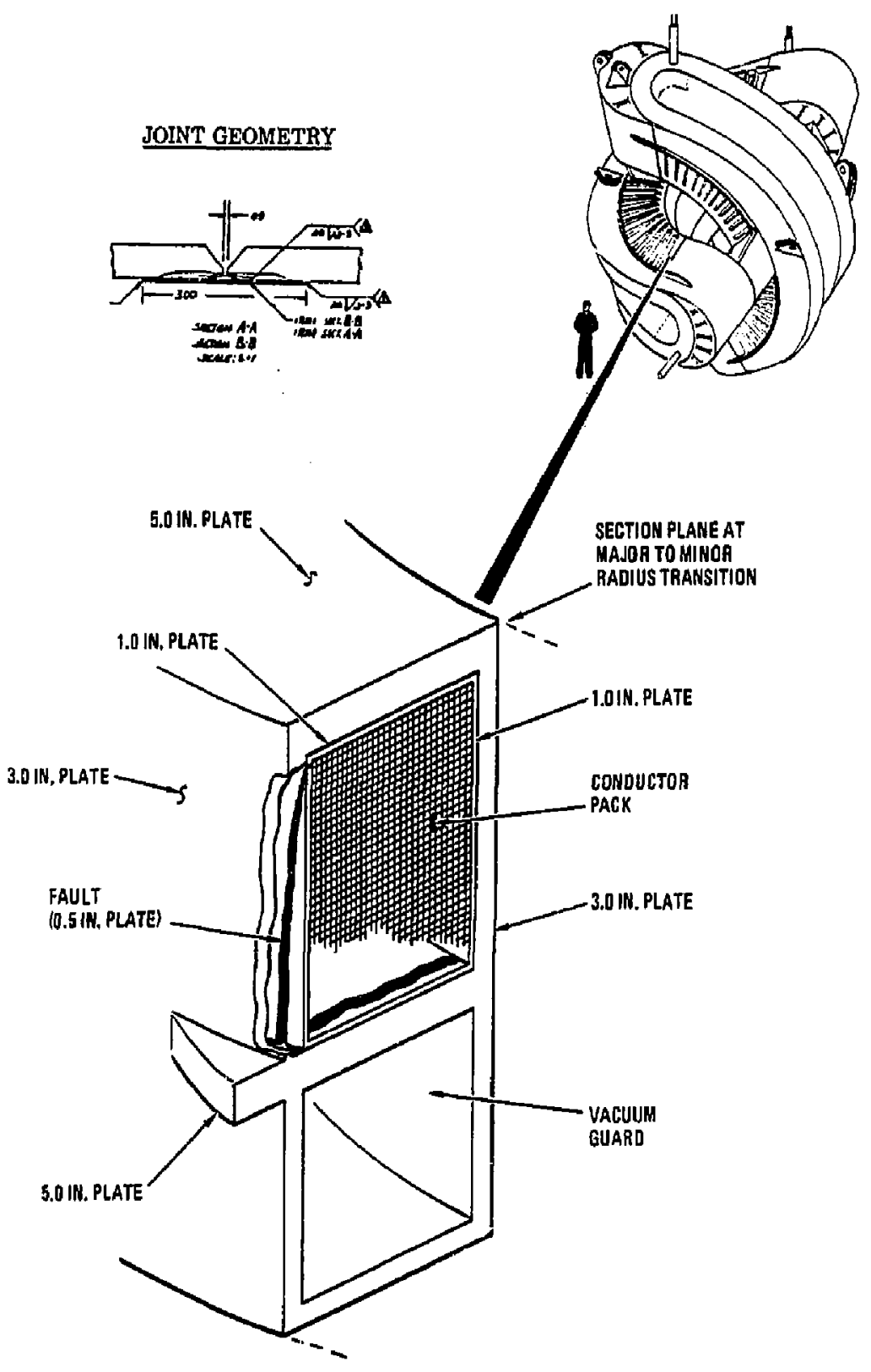

F1gure 3.8. Fault Condition Number 2 
- Concern

- Decreased weld inspectability increases probabllity of potentlally critical flaw exdsting

- Previous stress analysis assumed that the jacket plating contributed to the case stiffness. Jacket fallure will increase the primary case plate stresses

\subsubsection{ANALYSIS METHODOLOGY}

At the fault location, colncident grid points were ingtalled aloag the entire 0.5" plate " $L "$ section as it was assumed the trangition from 0.5 " to 1. 0 " jacket plating would act as a crack arrest mechanism. Continuity was provdded for an all case plating while contlnuity of the $0.5^{\prime \prime}$ jacket plate was interrupted at the plane in question.

\subsubsection{ANALYSTS RESULTS}

Figures 3.9 and 3.10 display the longitudinal stresses that are normal to the assumed fault. These stresses were derived by extracting corner node displacement data from the SAP analysis computer output and performing simple $\Delta l / l$ calculations. At the fault location. plane No. 8 , it can be seen that the local stress at the top of the " $\mathrm{L}$ " section is compressive in nature and therofore will not encourage fault propagation (Mode I). The local stress at the bottom of the "L" section (FIgure 3.10) is approxdmately $40,271 \mathrm{psi}$ tension and will promote fault propagation. It is interesting to note that ior the baselire analysis, this same area had a local tension stress of $40,015 \mathrm{psi}$ (see Figure 3.4).

Assuming an $0.5^{\prime \prime}$ edge crack in a infinite plate (the remaining $1.0^{\circ 1}$ " $\mathrm{L}$ " section) a Mode I stress intensity may be calculated from the following expression

$$
\begin{aligned}
K_{I} & =1,1215 \sigma \sqrt{\pi a} \quad \text { (Ref. 3) } \\
& =40015 \sqrt{0.5 \pi} \\
& =50 \mathrm{ksi} \sqrt{\mathrm{in} .}
\end{aligned}
$$

Comparison of the calculated and critical stress intensity values indicates that this fault would continue to propagate under cyclic loading, but comparison of the fault plate results and baseline plate results indicates that loss of this jacket stlfiness would not have a significant effect on the local stress distribution of the case. 


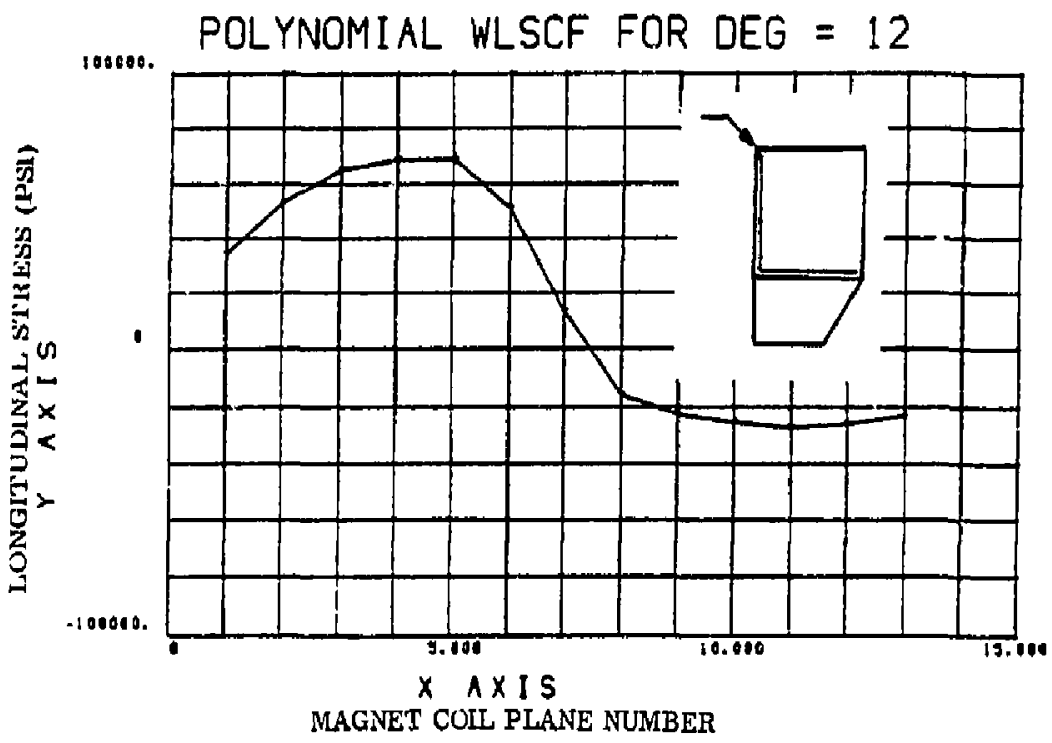

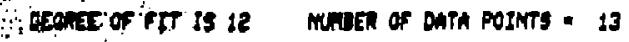

codifictentst. Q, $2,3, \ldots$ beches) ane

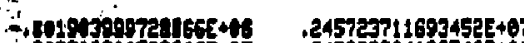

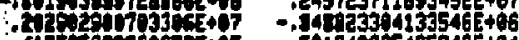

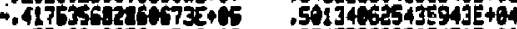

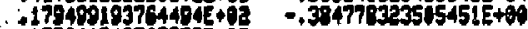

+15J412427076te-03

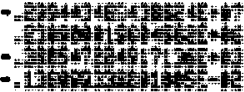

mear of Restouals - $-2.686507435-20$

ONE SICMA RESIDUAT - 2,6ES40EBIE-HP

UMIANCE of REStouals - $5.09273909 E-16$

Figure 3.9. Fault No. 2 - Longitudinal Stresses at Top of L Section 0.5 in. Jacket Close-Out Plate 


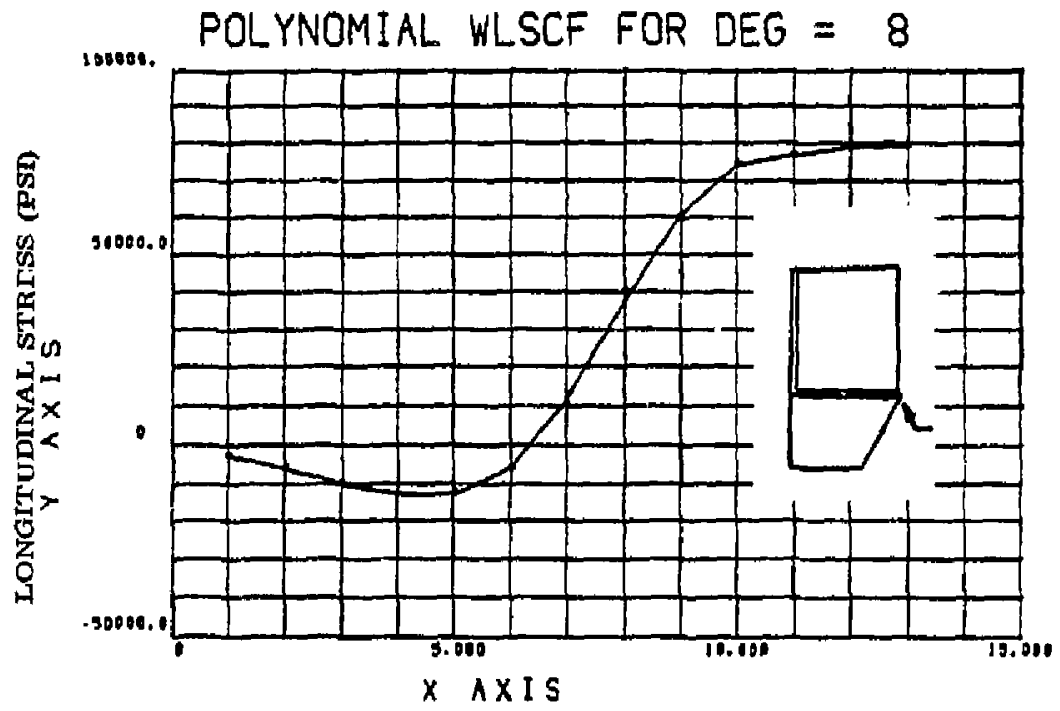

MAGNET COIL PLANE NUMBER

DeEaE of FIT is 1 mundh of DATh points - 23

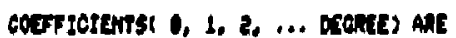

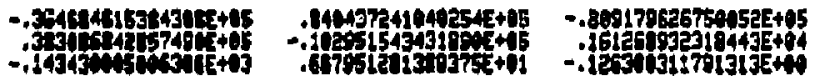

nem of nestounts - -7.3978state-10

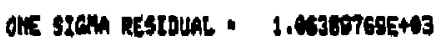

vaniance of Rastouats - 1.2310713ik+16

Figure 3.10. Fault No. 2 - Longltudinal Stresses at Bottom of L Section 0.5 in. Jacket Close-Out Plate 


\subsection{FAULT NO, 3: INTERCOIL MEMBER SHEAR TRANSFER WELD, BOTTOM CLOSIIRE PLATE TO SIDE PLATE CORNER WELD}

\subsection{SELECTION RATIONALE}

The intercoil fault condition is shown graphically in Figure 3.11. The selection rationale for this fault follows:

- Weld Joint

- Joint Geometry - No Significant Effect

- Stress

- Compressive Only

- Concern

- Loss of Joint May Cause Intercoil Member Instability and System Catastrophic Failure

\subsubsection{ANALYSIS METHODOLOGY}

Coincident grid points were installed along the intercoil member fault comer. The plate connectivity was altered so there could be no load transfer between the bottom and side plate locally along the fault perimeter.

\subsubsection{ANALYSIS RESULTS}

Figures 3.12 and 3.13 present the plate membrane stresses in the intercoil structure for the normal operating magnetic condition for the baseline model (connectivity scheme No. 6) and the intercoil fault condition, respectively.

Principal stress and factor of safety calculations were performed at locations 1 and 2 for both models; results are presented below.

\begin{tabular}{|l|l|l|l|l|}
\hline Location/ & \multicolumn{2}{|c|}{ Principal Stress (psi) } & \multicolumn{2}{c|}{ Margin of Safety* } \\
\cline { 2 - 5 } CQUAD No. & Baseline & Fault & Baseline & Fault \\
\hline $1 / 1720$ & -63700 & -55300 & 0.88 & 1.17 \\
$2 / 1724$ & -36800 & -35300 & 2.26 & 2.40 \\
\hline
\end{tabular}

*Based on a compressive yield allowable of $120 \mathrm{ksi}$.

Implications of this analysis are inconclusive as review of the finite element results of this simulated fault condition indicate no significant redistribution of stresses. 


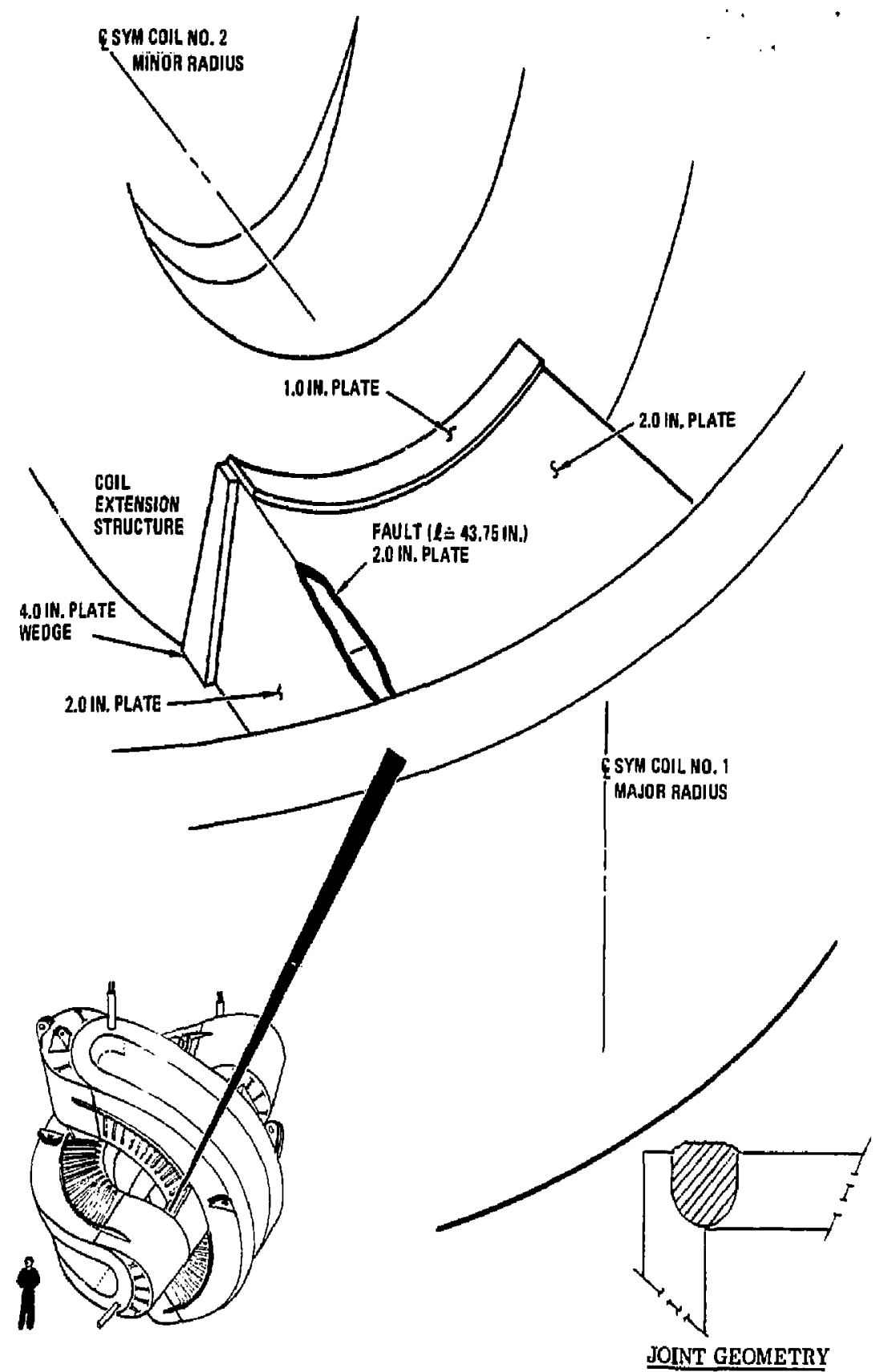

Figure 3.11. Fault Condition Number 3 
(723)

(719)

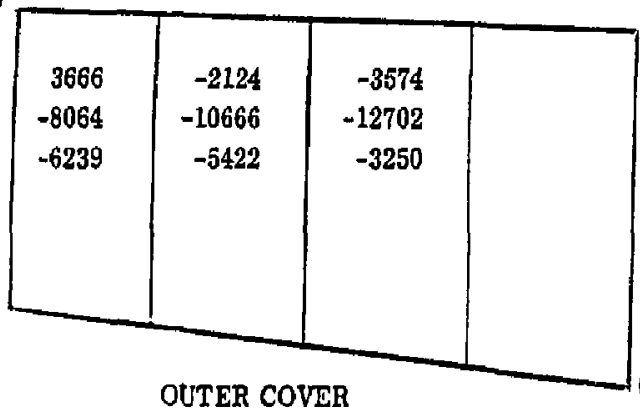

(451)<smiles>CC</smiles>

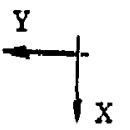

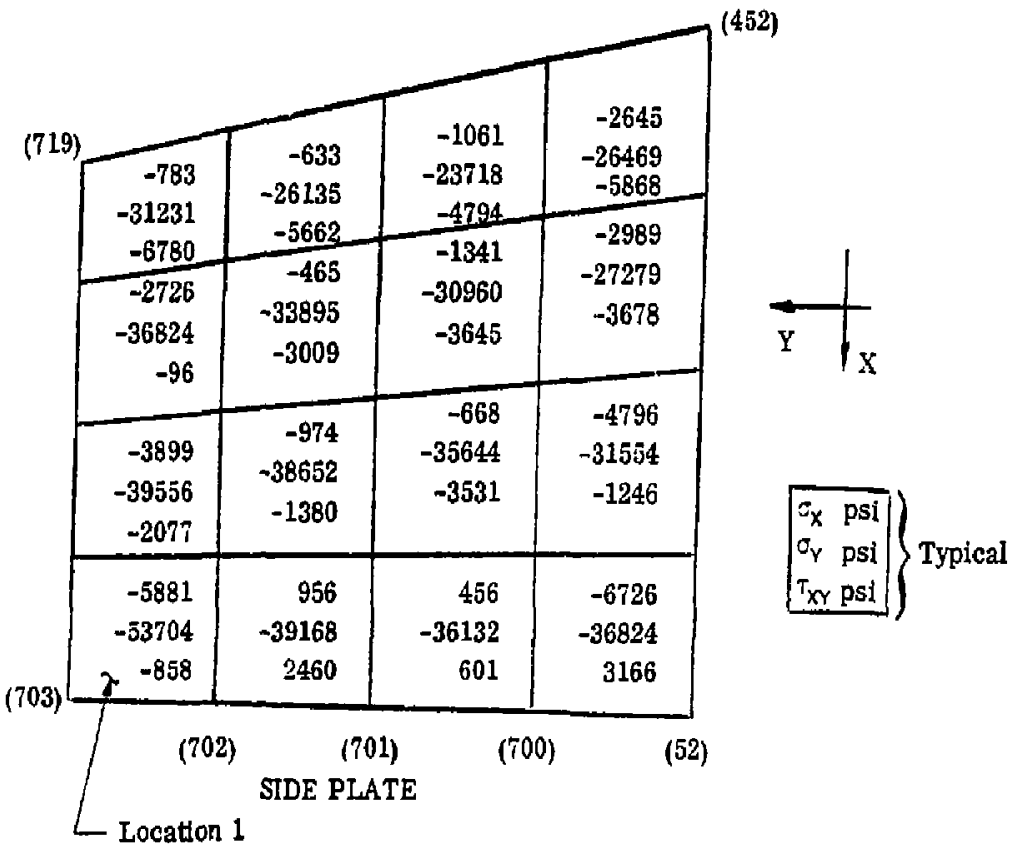

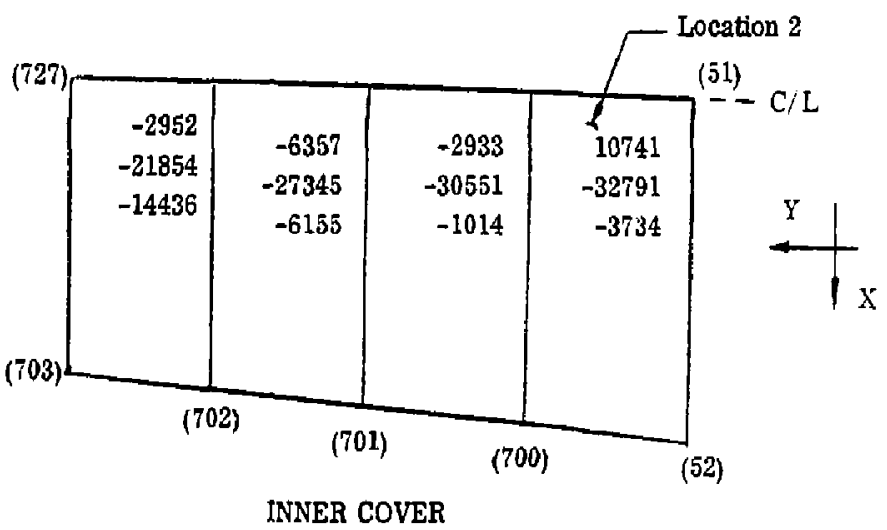

Figure 3.12. Intercoll Structure Loads for Baseline No. 6 (Magnetic Loads Only) 
(723)

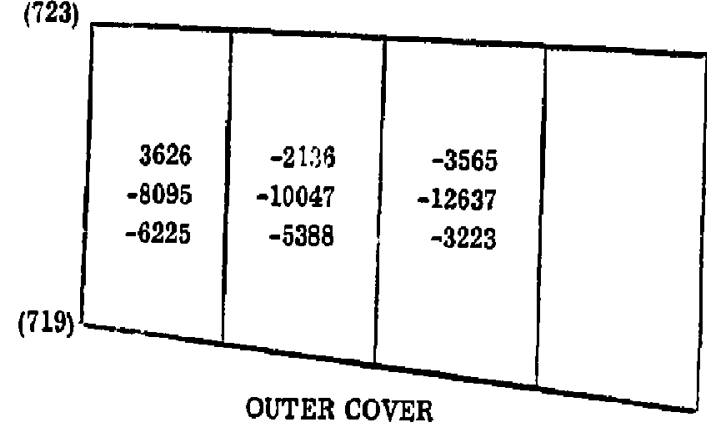

(451)

$--\mathrm{c} / \mathrm{L}$

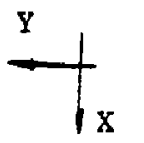

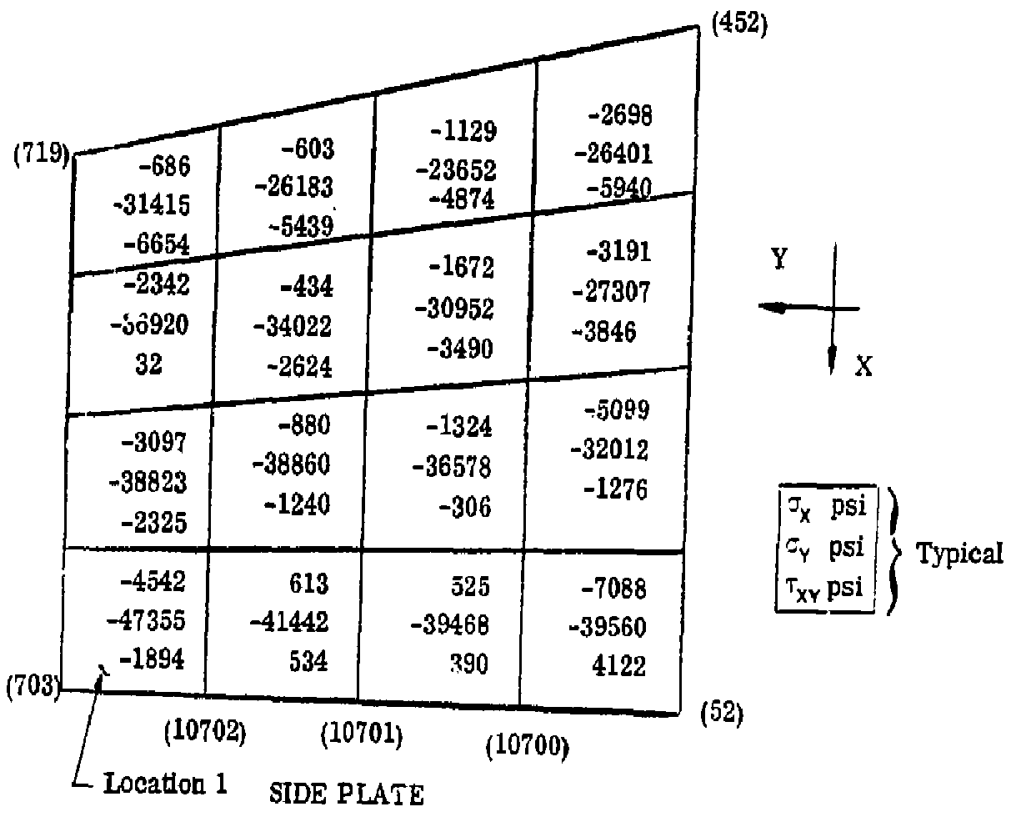

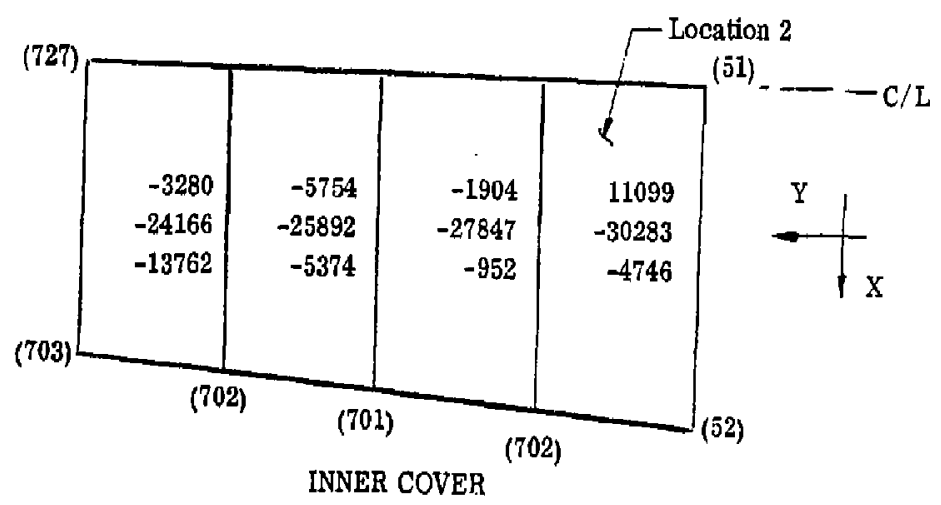

Figure 3.13. Intercoll Structure Loads for Fault No. 3 (Magnetic Loads Only) 


\subsection{FAULT NO. 4: 3-INCH PLATE CLOSE-OUT WELD AT THE CENTER LINE OF SYMMETRY IN THE MINOR RADIUS AT THE BOTTOM OF THE 9 SECTION}

\subsubsection{SELECTION RATIONALE}

An isometric sketch of the fault condition is shown in Figure 3.14. The selection rationale for this fault condition follows:

- Weld Joint

- Close-out Weld; Increases Weld Inspection Difficulty

- Joint Geometry

- Not Significant

- Stress

- Moderate Plate Longitudinal Membrane Stress (Ref. 1)

- Concern

- Decreased weld inspectability increases probability of potentially critical flaw existing. Joint failure and subsequent redistribution of stresses may result in excessive deflections and conductor pack crushing

\subsubsection{ANALYSIS METHODOLOGY}

The fault was assumed to extend from the minor radius center line of symmetry through a 20-degree arc (half length $=6.82 \mathrm{in}$.). Coincident grid points were installed in the baseline mudel along exdisting fault line grid points. Continuity of the 3- to 5-inch plate joint was interrupted by redefining existing CQUAD element grid point connectivities.

\subsubsection{ANALYSIS RESULTS}

Deflection data near the approaching fault front was extracted from the computer output for use in a Mode I fracture analysis. From this deflection data the local plate membrane stress was determiner to be approximately 5,667 psi. From linear elastic mechanies theory, for an infinite plate with a flnite center crack,

$$
K_{I}=\sigma \sqrt{\pi a}
$$

substituting in $\sigma=5,667$ psi and a $=6.82^{\prime \prime}$ yields

$$
\mathrm{K}_{\mathrm{I}}=5667 \sqrt{6.82 \pi}=26.23 \mathrm{ksi} \sqrt{\mathrm{in}} \text {. }
$$




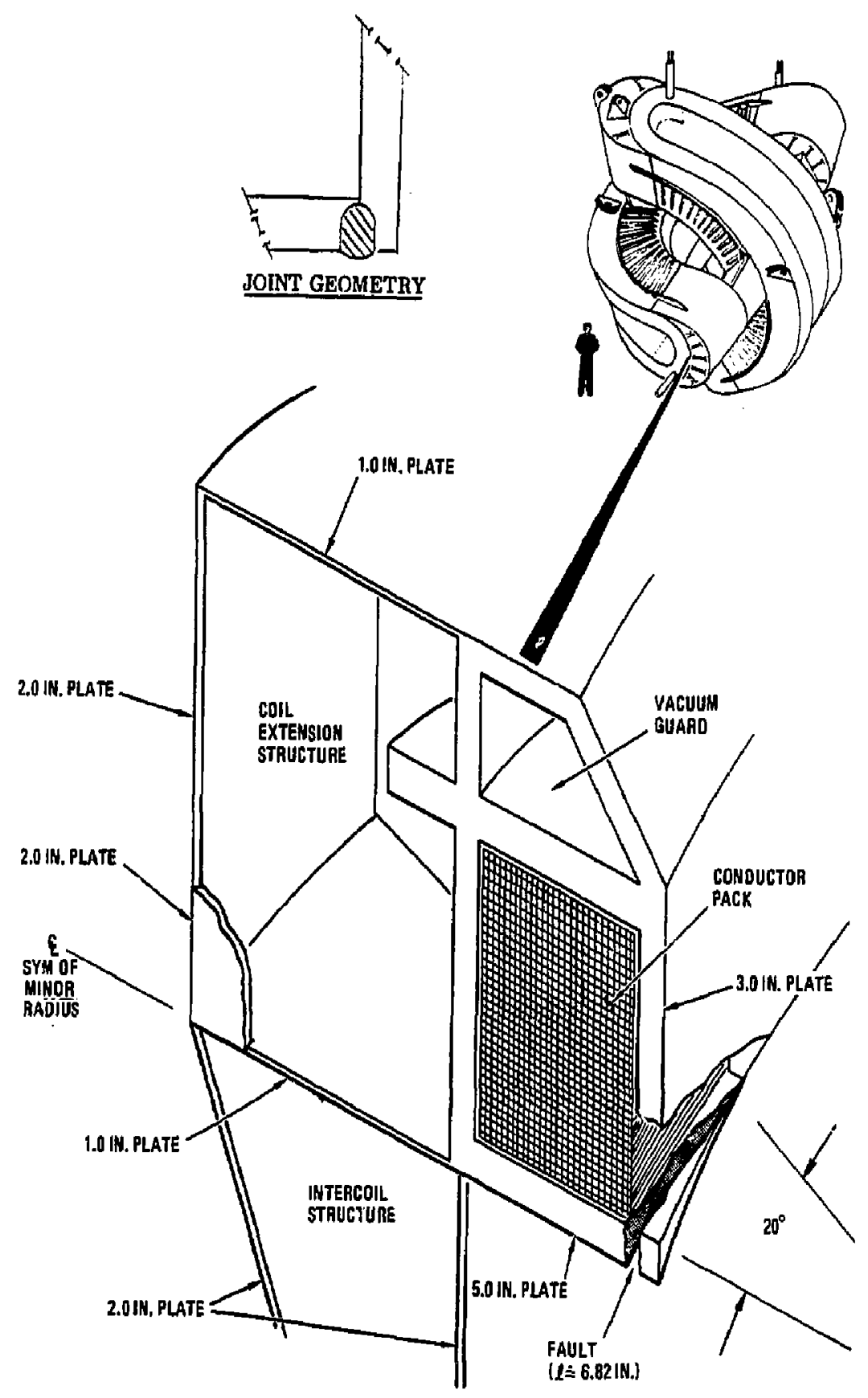

Figure 3.14. Fault Condition Number 4 
As previously noted, $\mathrm{K}_{\mathrm{IC}}$ for E316 weld filler metal at $4.5 \% \mathrm{~K}$ is $95 \mathrm{ksi} \sqrt{\text { in. }}$ Comparison of the calculated stress intensity factor and the critical stress intensity indicates that this fault will continue to propagate under cyclic loading until fallure or a crack arrest mechanism is encountered.

\subsection{FAULT NO. 5: MAJOR TO MINOR RADIUS TRANSITION, 3 TO 5 INCH BUTT WELD JONT ONT THE CONDUCTOR CASE TOP PEATE}

\subsubsection{SELECTION RATIONALE}

The selection rationale for this fault (see Figure 3.15 for an isometric illustration) was as follows:

- Weld Joint

- One Sided Butt Jolnt (Unbalanced)

- Weld Bead Reinforcement on $\left(\mathrm{K}_{\mathrm{T}}\right)$

- Heat Sink Gradient

- Joint Geometry

- 3 to 5 Inch Plate Transition Produces Local Stress Raiser

- Stress

- Plate Membrane Stresses Normal to This Joint .Approach 60 ksi (Ref, 1)

- Transverse Secondary Bending Moments Approach 95 in-kips/in. (Ref. 1)

- Concern

- Joint fallure causes a significant reduction in magnet section modulus resulting in redistribution of stresses and possible system catastrophic fallure

\subsubsection{ANALYSIS METHODOLOGY}

The existing baseline model was modified to reflect coincldent grid point along the fault line. Plate connectivities were modified such that load could not be transferred across the fault line.

\subsubsection{ANALYSIS RESULTS}

Figures $3.16,3.17$ and 3.18 present plate membrane, bending and principal stresses for selected case elements for the fault and baseline firite element models. Review of these figures indicates significant changes in the local stress flelds around the fault. Figures 3.19 and 3.20 present longitudinal plane membz:ne stresses which 


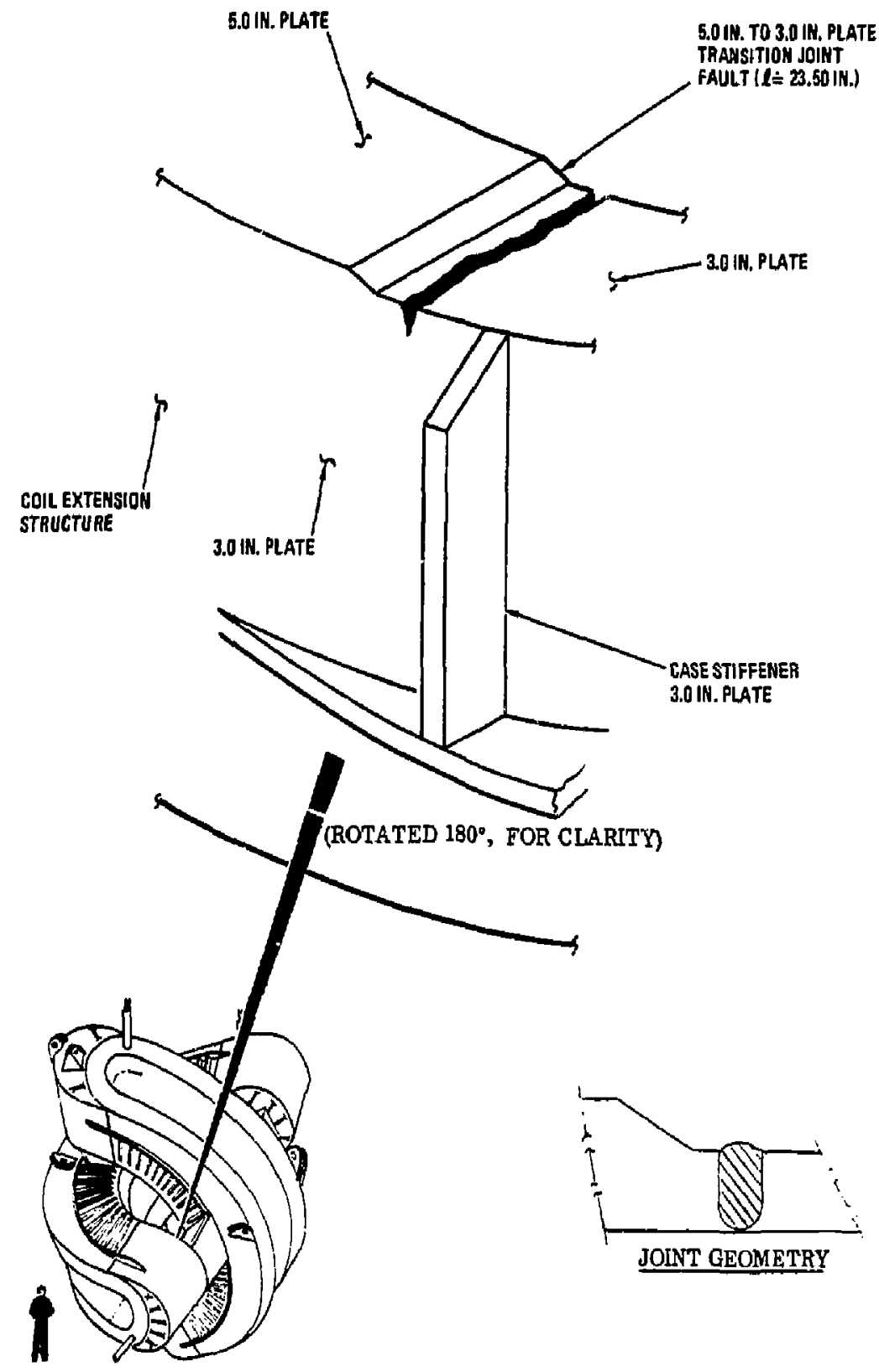

Figure 3.15. Fault Condition Number 5 

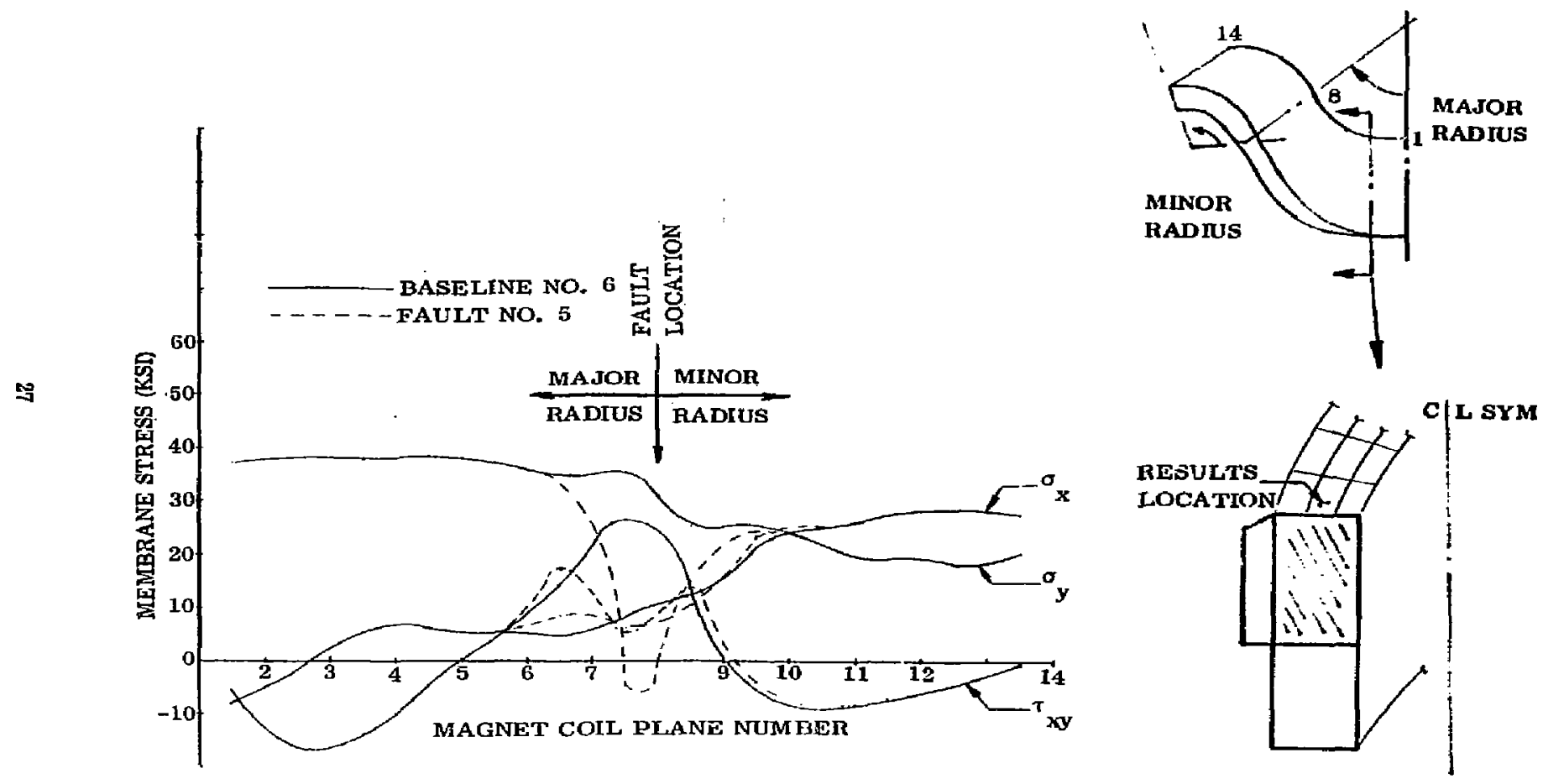

Figure 3. 16. Fault No. 5 - Baseline Model Plate Membrane Stress Comparison 

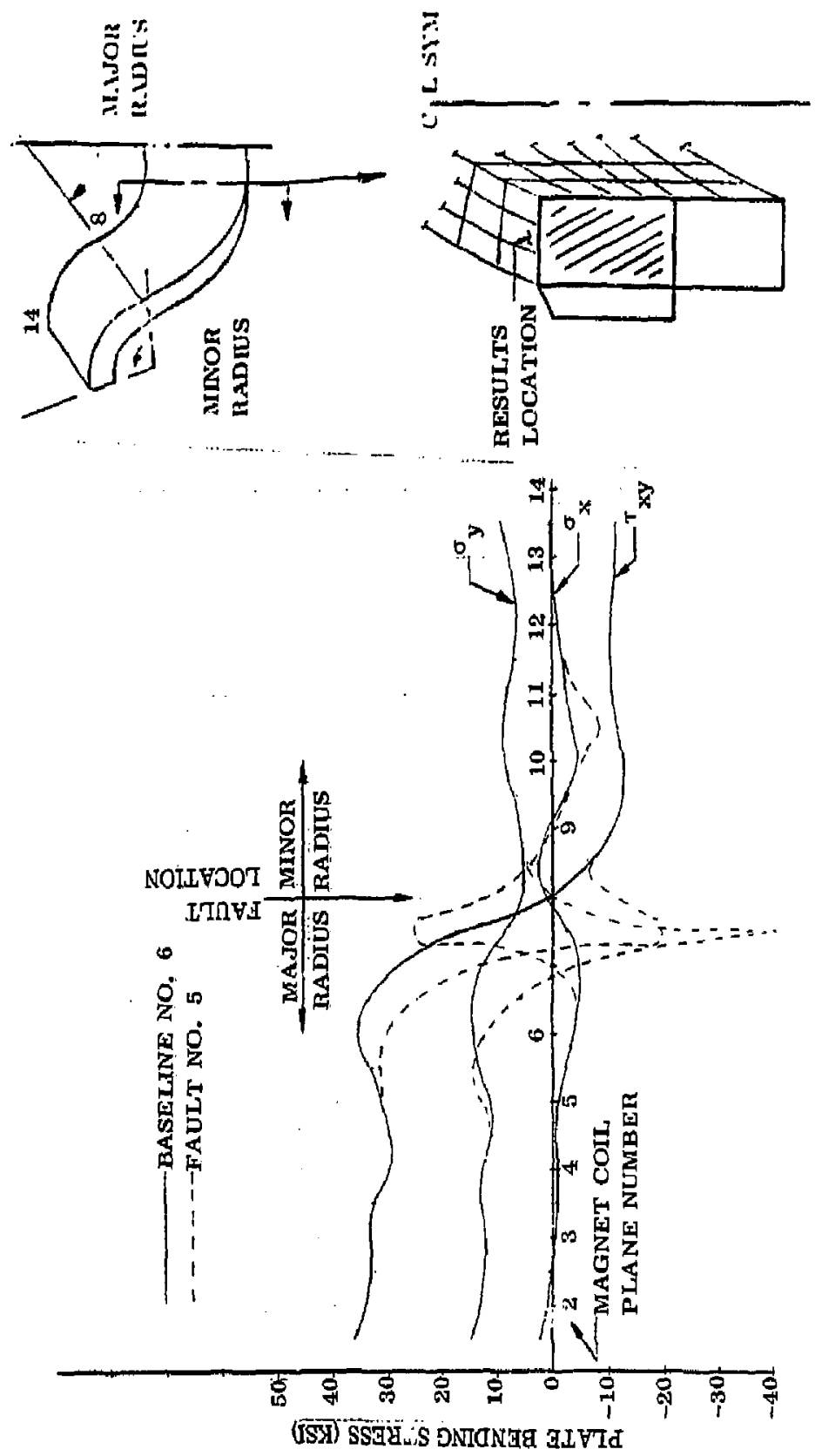

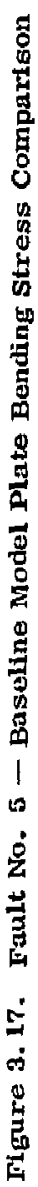



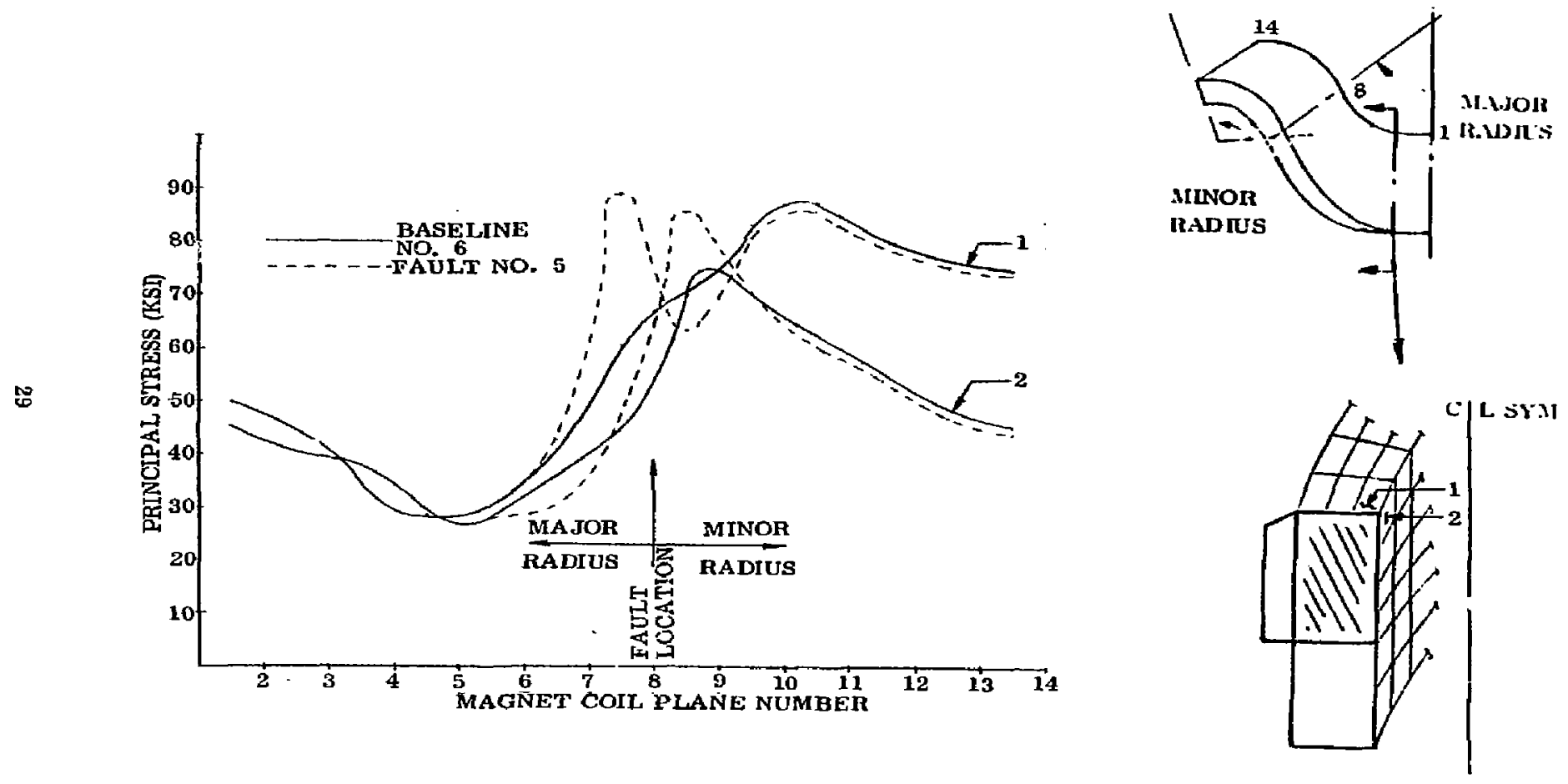

Figure 3. 18. Fault No. 5 - Baseline Model Selected Plate Principal Strese Comparison 


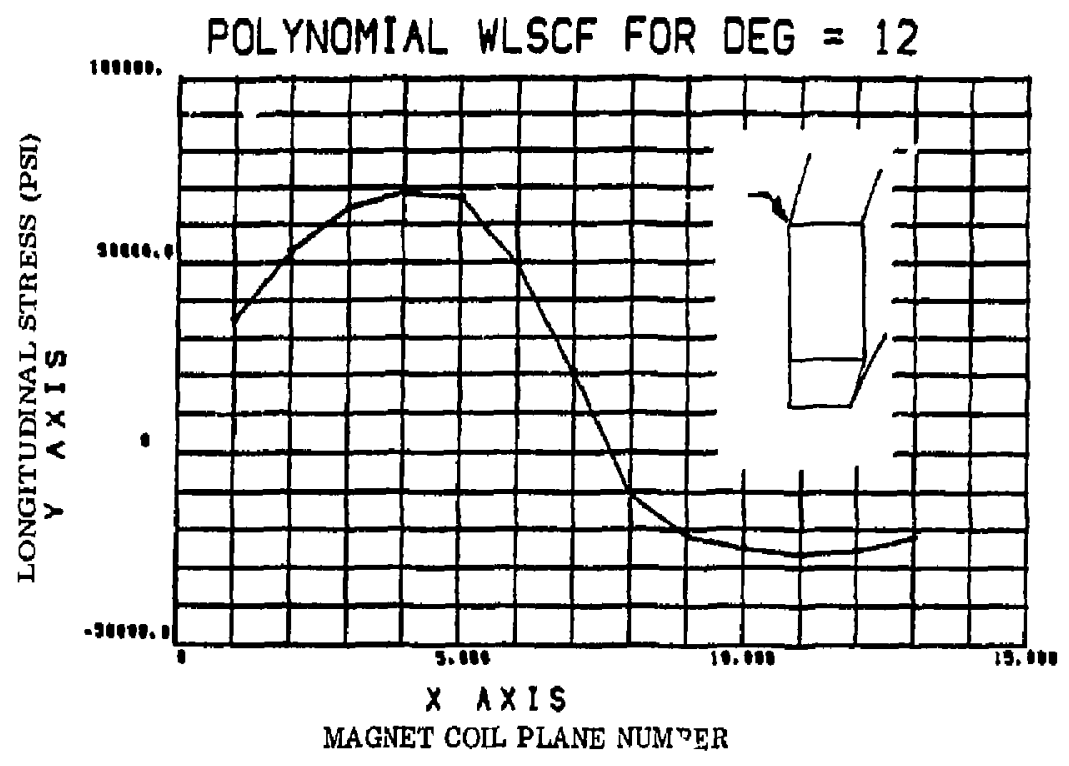

Decket of frt ts it mane of anth polms - 13

cotpheientst $0,1,2, \ldots$ Monei ane

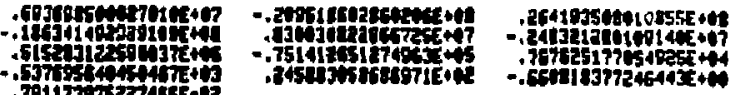

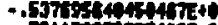

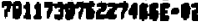

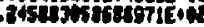

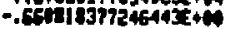

Figure 3.19. Fault No. 5: Longitudinal Stresses Along Case Top outside Comer 


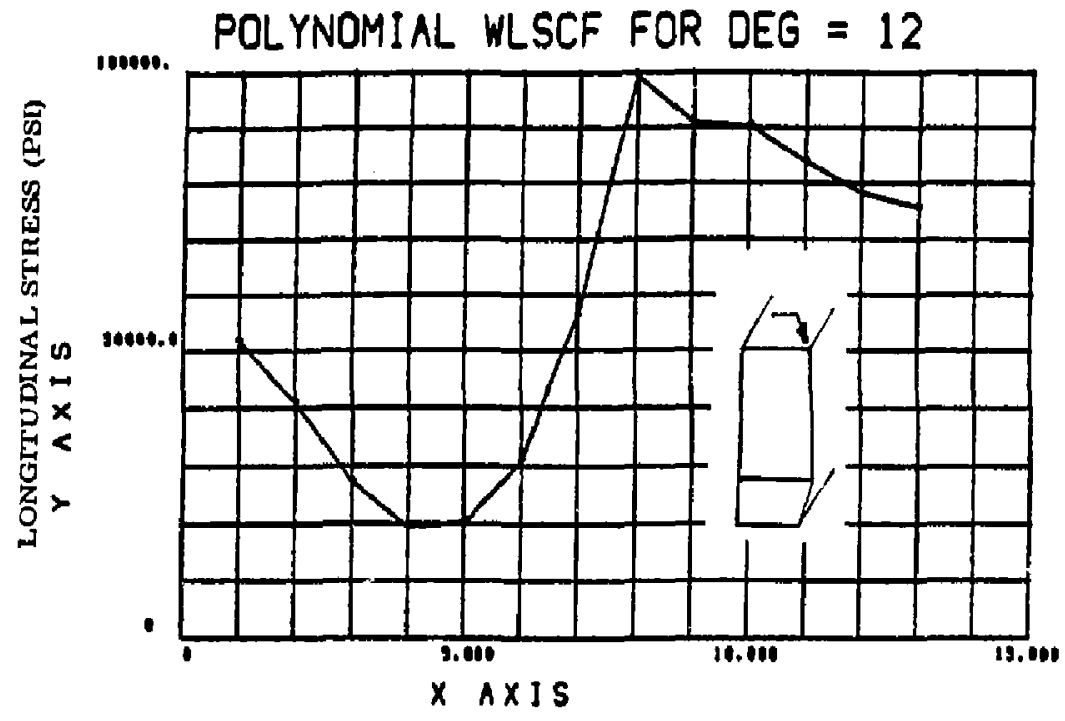

MAGNET COIL PLANE NUMBER

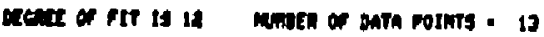

cotricigirst $0,1,8, \ldots$ mentes ate

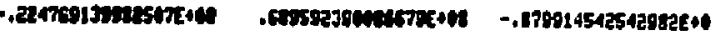

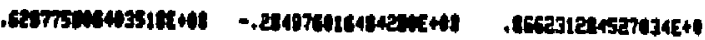

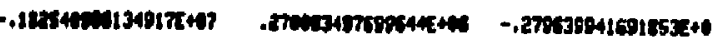

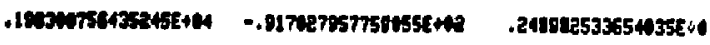

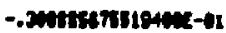

Figure 3.20. Fault No. 5: Longitudinal Stresses Along Case Top Inside Corner 
are perpendicular to the approaching fault front. At plane 8 (Ftgure 3.20) in the victnity of the fault, these stresses approach $39,311 \mathrm{psi}$. For the baseline analysis, these stresses were calculated to be $87,887 \mathrm{psi}$.

Again, if we assume an edge crack in an infinite plate, then

$$
\mathrm{K}_{\mathrm{I}}=1.1215 \sigma \sqrt{\pi \mathrm{a}}
$$

Setting $\sigma=99311 \mathrm{psi}$ and $\mathrm{a}=\mathbf{5 . 0 "}$ in the above expression yields

$$
\begin{aligned}
K_{\text {I }} & =1.1215 \times 99311 \sqrt{5 \pi} \\
& =441 \mathrm{ksi} \sqrt{\text { in. }}
\end{aligned}
$$

As compared to the crittcal stress intensity factors for E316 weld filler and $304 \mathrm{LN}$ (95 and $203 \mathrm{ksi} \sqrt{\mathrm{Ln}}$. respectively), this calculated $\mathrm{K}_{\mathrm{I}}$ reflects a catastrophic failure. 


\section{CONCLUSIONS}

Results of this study are summarized in Table 4.1. Of the five fault conditions analyzed, two are considered to have structurally catastrophic effects; catastrophic meaning these faults would be reflected by sudden and volent changes in the geometry of the structure. The two faults considered structurally catastrophic (Mode I analysis) were:

FauIt No. 1 - Minor radius intermediate 3 to 5 inch plate intersection in the chamfer reglon at the centerline of symmetry.

Fault No. 5 - The 3 to 5 inch transition butt weld joint at the major to minor radius transition on the conductor case top plate.

Fault No. 4, the 3-inch plate close-out weld at the center line of symmetry in the minor radius at the bottom of the 9 section, is considered to be potentially catastrophic; i. e., the calculated stress intensity factors are lower than the critical stress intensity factor but under cyclic loading this fault will continue to propagate until repaired or a suitable crack arrest mechanism is encountered.

Review of the $a^{r}$.alysis for Fault No. 2, the fallure of the close-out weld in the 0.5inch jacket plate at the major to minor radius transition indicates that the jacket will fail under cyclic loading. However, this local fallure should not significantly affect the structural integrity of the magnet system.

Conclusions about the intercoil member fault condition are somewhat different as this member is basically in compression and faults cannot propagate. Review of the analysis results do not indicate any significant redistribution of stresses in the fault area. This is probably a consequence of the modeling technique which employed a relatively large mesh size. Additional study in this area does not appear to be warranted. 
Table 4.1. Results Summary

\begin{tabular}{|c|c|c|c|}
\hline $\begin{array}{c}\text { Fault } \\
\text { No. }\end{array}$ & Fault Description & $\begin{array}{l}\text { Calculated } \\
\mathrm{K}_{\mathrm{I}} \text { or } \mathrm{MS}\end{array}$ & Discussion \\
\hline $\mathbf{1}$ & $\begin{array}{l}\text { Minor radius intermediate } 3 \text { to } 5 \text { inch } \\
\text { plate intersection in the chamfer } \\
\text { region at the center line of symmetry }\end{array}$ & $120 \mathrm{kgi} \sqrt{\mathrm{In}}$. & $\begin{array}{l}\mathrm{K}_{\mathrm{I}} \text { higher than } \mathrm{K}_{\mathrm{IC}} \\
\text { Fault will be self propagating } \\
\text { Catastrophic fallure assumed }\end{array}$ \\
\hline 2 & $\begin{array}{l}\text { Conductor pack jacket close-out } \\
\text { weld in the major to minor radius } \\
\text { transition }\end{array}$ & $50 \mathrm{kgl} \sqrt{\mathrm{ln}}$ & $\begin{array}{l}K_{I} \text { lower than } K_{I C} \\
\text { Fault will propagate under cyclic loading } \\
\text { Overall system integ'ity not signiftcantly } \\
\text { affected }\end{array}$ \\
\hline 3 & $\begin{array}{l}\text { Intercoll momber shear transfer weld, } \\
\text { bottom olosure plate to side plate } \\
\text { corner weld }\end{array}$ & M.S. $=1.17$ & $\begin{array}{l}\text { m.s. calculated assiming compression } \\
\text { yield allowable of } 120 \mathrm{ksi} \\
\text { Additional analysis requi red }\end{array}$ \\
\hline 4 & $\begin{array}{l}\text { 3-inch plate close-out weld at the } \\
\text { center line of symmetry in the minor } \\
\text { radius at the bottom of the } 9 \text { gection }\end{array}$ & $26 \mathrm{ksl} \cdot \sqrt{\mathrm{in}}$ & $\begin{array}{l}K_{I} \text { lower than } K_{I C} \\
\text { Fault will propagate under oyclic logding }\end{array}$ \\
\hline 5 & $\begin{array}{l}3 \text { to } 5 \text { inch trangition butt weld joint } \\
\text { at the major to minor radius iransition } \\
\text { on the conductor cage top plate }\end{array}$ & $441 \mathrm{ksi} \sqrt{\mathrm{ln}}$ & $\begin{array}{l}K_{I} \text { higher than } K_{I C} \\
\text { Fault will be self propagating } \\
\text { Catastropho failure assumed }\end{array}$ \\
\hline
\end{tabular}




\section{RECOMMENDATIONS}

As a result of this stady the following recommendations are made:

1. A periodic magnet inspection plan should be cieveloped and implemented.

2. In order to more accurately represent the structural behavior in the presence of a crack tip, future fault analyses of this type should utilize a non-linear finite element code (such as MARC) that has that capability.

3. If a linear code such as GDSAP is used for future fault analysis purposes, the mesh size adjacent to fault boundaries should be recuced to more accurately predict local peaking effects. 


\section{REFERENCES}

1. Structural Analysis of the Magnet System for Mirror Fusion Test Facility (MFTF), GD/C Report No. CASD-LLL-78-003, by J. W. Wohlwend, et al, October 1978.

2. Conductor Stress Analysis for the Mirror Fusion Test Facility (MFTF) Magnet System, GD/C Report No. GDC-LLL-79-001, by R. W. Baldi and C. D. Poniktera, March 1979.

3. The Stress Analysis of Cracks Handbook, by Kiroshi Tada, Del Research Corporation, 1973.

NOTICE

"Work performed under the auspices of the U.S. Department of Energy by the Lawrence Liver. more Laboratory under contract number $w$. 7405-ENG-48."

"This report was prepared as an account of wark sponsored by the United Stales Government. Neilher the United States nor the United States Department of Energy, nor any of their etnployees, nor any of thejr contractors, subwontras. tors, or their employees, makes iny wartanty, ex. press or implied, or assumes any legal liability or responsibility for the accuracy, compleicness or usciulness of any information, appasatus, product or prosess disclosed, or represents that ils use would not infringe p vatcly.owned rights."

Reference to a company or producl same does not imply approval or rceommendalion of the product by the University of California or the U.S. Department of Energy to the exclusion of others tha! may be suitable. 